1 Short title: $\mathrm{Zn}$ transport-related genes in biofortified alfalfa

Article title:

4 Transcriptional regulation of genes involved in $\mathrm{Zn}$ transport after foliar $\mathrm{Zn}$ application to

\title{
Medicago sativa
}

6 Alessio Cardini $^{\mathrm{a}^{*}}$, Elisa Pellegrino ${ }^{\mathrm{a}+*}$, Philip J. White ${ }^{\mathrm{b}}$, Barbara Mazzolai ${ }^{\mathrm{c}}$, Marco C. Mascherpa ${ }^{\mathrm{d}}$,

$7 \quad$ Laura Ercoli $^{\mathrm{a}}$

8 a Institute of Life Sciences, Scuola Superiore Sant'Anna, Piazza Martiri della Libertà 33, 56127 Pisa,

9 Italy

$10{ }^{\mathrm{b}}$ Departmnent of Ecological Science, The James Hutton Institute, Indergowrie, Dundee DD2 5DA,

11 United Kingdom

$12{ }^{\mathrm{c} C e n t e r}$ for Micro-BioRobotics, Istituto Italiano di Tecnologia, Viale Rinaldo Piaggio 34, 56025

13 Pontedera, Pisa, Italy

$14{ }^{\mathrm{d}}$ National Research Council of Italy, C.N.R., Istituto di Chimica dei Composti OrganoMetallici - SS 15 of Pisa, Italy

${ }^{+}$Corresponding author: Elisa Pellegrino

18 Email: elisa.pellegrino@santannapisa.it

*These authors contributed equally to the work

\section{One-sentence summary:}

23 Upregulation of ZIP2, NAS1 and HMA4 and downregulation of ZIP3 are associated with $\mathrm{Zn}$ sequestration and shoot-to-root translocation in Medicago sativa following foliar Zn biofortification

\section{ORCID}

Alessio Cardini https://orcid.org/0000-0001-9687-6047

Elisa Pellegrino https://orcid.org/0000-0002-2482-1327 
30 Barbara Mazzolai https://orcid.org/0000-0003-0722-8350

31 Marco Carlo Mascherpa https://orcid.org/0000-0001-5816-0953

32 Laura Ercoli https://orcid.org/0000-0002-7942-2120

33

\section{Author contributions}

35 EP and LE conceived the ideas; AC, EP, LE designed the methodology; AC and BM designed and

36 performed real-time PCR; AC and CM performed chemical analyses; AC and EP performed data analysis; AC, EP, PJW, LE led the writing of the manuscript; all authors contributed critically to the drafts and gave final approval for publication. 


\section{ABSTRACT}

41 Zinc $(\mathrm{Zn})$ is an essential micronutrient for both plants and animals, and $\mathrm{Zn}$ deficiency is one of the most widespread problems for agricultural production. Although many studies have been performed on the biofortification of staple crops with $\mathrm{Zn}$, few studies have focused on forage crops. In this study the molecular mechanisms of $\mathrm{Zn}$ transport-related in Medicago sativa $\mathrm{L}$. were investigated following foliar $\mathrm{Zn}$ applications aimed at increasing the accumulation of $\mathrm{Zn}$ in edible tissues. Zinc uptake and redistribution between shoot and root were determined following the application of six $\mathrm{Zn}$ doses to leaves $\left(0,0.01,0.1,0.5,1,10 \mathrm{mg} \mathrm{Zn} \mathrm{plant}^{-1}\right)$. Twelve putative genes encoding proteins involved in Zn transport (MsZIP ${ }_{1-7}, M s Z I F 1, M s M T P 1, M s Y S L 1, M s H M A 4$ and MsNAS1) were identified and the changes in their expression following foliar $\mathrm{Zn}$ application were quantified using newly designed RT-qPCR assays. Shoot and root Zn concentration was increased following foliar Zn applications $\geq 0.1 \mathrm{mg}$ plant $^{-1}$. Increased expression of MsZIP2, MsHMA4 and MsNAS1 in shoots, and of MsZIP2 and MsHMA4 in roots, was observed with the largest $\mathrm{Zn}$ dose. By contrast, MsZIP3 was downregulated in shoots at $\mathrm{Zn}$ doses $\geq 0.1 \mathrm{mg} \mathrm{plant}^{-1}$. Three functional modules were identified in the $M$. sativa response to foliar $\mathrm{Zn}$ application: genes involved in $\mathrm{Zn}$ uptake by cells, genes involved in vacuolar $\mathrm{Zn}$ sequestration and genes involved in $\mathrm{Zn}$ redistribution within the plant. These results will inform genetic engineering strategies aimed at increasing the efficiency of crop Zn biofortification.

\section{KEY WORDS:}

Zinc, micronutrient, biofortification, alfalfa (Medicago sativa), ZIP transporters, Nicotianamine, Heavy Metal transporters (HMA), cellular zinc homeostasis. 


\section{INTRODUCTION}

Food quality is a key factor for human health (Geissler and Powers, 2017). For their well-being, humans require sufficient quantities of at least 18 mineral elements, which have specific physiological roles and are irreplaceable in the diet (White, 2016). Eight essential macronutrients (i.e., $\mathrm{N}, \mathrm{P}, \mathrm{S}, \mathrm{Ca}, \mathrm{Mg}, \mathrm{K}, \mathrm{Na}, \mathrm{Cl})$ are required in large amounts in the diet (> $100 \mathrm{mg} \mathrm{day}^{-1}$ ), and 10 micronutrients are required in smaller amount (e.g., $\mathrm{Zn}, \mathrm{Fe}, \mathrm{F}, \mathrm{Mn}$ ). The main sources of these elements in the human diet include edible crops, animal products (e.g., meat, fish, eggs) and dairy products (e.g., milk, cheese, butter) as well as mineral supplements (Keen, 1990; Prasad, 2013; White, 2016). A large proportion of the world's population suffers from $\mathrm{Zn}$ related diseases (i.e., malabsorption syndrome, liver disease, chronic renal disease, sickle cell disease and other chronic diseases), since it relies on cereal-based diets with low $\mathrm{Zn}$ content due to poor soil Zn availability (WHO, 2005; Alloway, 2009; Prasad, 2013; Kumssa et al., 2015; Cakmak et al., 2017). Diversification of the human diet and biofortification of edible crops are therefore needed to alleviate $\mathrm{Zn}$ deficiency in humans. Similarly, increasing $\mathrm{Zn}$ concentrations in forage crops are important for maintaining livestock health and the quality of food products, which affect human health indirectly (McDonald et al., 2002; Ciccolini et al., 2017; Capstaff and Miller, 2018; Huma et al., 2019).

Zinc plays a major role as a co-factor of over 300 enzymes in plants and is an essential micronutrient (Broadley et al., 2007). Zinc is involved in various physiological functions, such as $\mathrm{CO}_{2}$ fixation, protein synthesis, free radical capture, regulation of growth and development, and disease resistance (Sasaki et al., 1998; Broadley et al., 2007). Many structural motifs in transcriptional regulatory proteins are stabilized by $\mathrm{Zn}$, such as $\mathrm{Zn}$ finger domains (Albert et al., 1998). Zinc deficiency reduces crop production, as does Zn excess (White and Pongrac, 2017). Excessive $\mathrm{Zn}^{2+}$ can compete with other cations in binding to enzymes and for transport across membranes, thereby impairing cellular activities (White and Pongrac, 2017). Thus, the uptake of $\mathrm{Zn}^{2+}$ by cells and its transport within the plant must be strictly regulated. Plant cells have evolved 
several homeostatic mechanisms for avoiding $\mathrm{Zn}^{2+}$ toxicity when exposed to large $\mathrm{Zn}$ availability in their environment. These include the reduction of $\mathrm{Zn}$ influx to cells, the stimulation of $\mathrm{Zn}$ efflux from the cytosol, the sequestration of $\mathrm{Zn}$ in vacuoles, and the chelation of $\mathrm{Zn}$ by $\mathrm{Zn}$ binding ligands. In general, the concentration of $\mathrm{Zn}$ in plant tissues must be kept between 15 to $300 \mu \mathrm{g} \mathrm{Zn} \mathrm{g}^{-1}$ dry matter (DM) to maintain cell structure and function (Broadley et al., 2012; White and Pongrac, 2017). Although tolerance to large tissue Zn concentrations varies among species (Alloway, 2008; White and Pongrac, 2017), Zn concentrations above 400-500 $\mu \mathrm{g} \mathrm{g} \mathrm{g}^{-1} \mathrm{DM}$ often cause toxicity symptoms including impaired root and shoot growth, chlorosis and necrosis of leaves, reduced photosynthesis, nutrient imbalance and ultimately loss of yield (Chaney, 1993; Broadley et al., 2007; Di Baccio et al., 2009; White and Pongrac, 2017).

The process of producing crops with greater mineral concentrations in edible tissues is called biofortification and provides a solution to the problem of mineral deficiencies in human and animal nutrition (White and Broadley, 2005). There are various approaches to $\mathrm{Zn}$ biofortification of edible crops, including agronomic strategies and conventional or transgenic breeding strategies. Agronomic biofortification aims to increase $\mathrm{Zn}$ concentrations in edible tissues through the application of $\mathrm{Zn}$-fertilisers to the soil or to leaves. It is relatively inexpensive and efficient (Saltzman et al., 2013). Foliar application of $\mathrm{Zn}$ is generally more effective than the application of Zn fertilisers to soil, since Zn uptake by plant roots is often limited by the low solubility of Zn salts, its binding to organic substrates, and its immobilization in the microbial biomass (Gregory et al., 2017). Both agronomic and genetic biofortification strategies have been studied extensively in cereal staple crops, such as rice, wheat and maize, but less in legumes, such as beans, peas or lentils (White and Broadley, 2005, 2011; Rawat et al., 2013). An international program, the HarvestPlus Zinc Fertilizer Project, is exploring the potential of $\mathrm{Zn}$ fertilisers to enhance the yields and $\mathrm{Zn}$ concentrations in edible portions of staple crops in developing countries of Africa, Asia and South America (www.harvestzinc.org) (Cakmak, 2012), but this program does not include forage crops. The natural direction of $\mathrm{Zn}$ flux in plants is from the soil via roots to the shoot and seeds (White 
118 and Broadley, 2009). Various transport proteins and ligands that are responsible for $\mathrm{Zn}^{2+}$ uptake by

119 roots and its transport and sequestration within the plant have been characterized (Olsen and

120 Palmgreen, 2014; Caldelas and Weiss, 2017; White and Pongrac, 2017). Among these, ZRT-IRT-

121 like Proteins (ZIPs), have been studied in several plants, including Arabidopsis thaliana, soybean

122 (Glycine max), barley (Hordeum vulgare), barrel medic (Medicago truncatula) and rice (Oryza

123 sativa) (Grotz et al., 1998; Zhao and Eide, 1996; López-Millán et al., 2004; Milner et al., 2013;

124 Tiong et al., 2015). These proteins not only transport $\mathrm{Zn}^{2+}$ across membranes, but can also transport 125 other transition metal cations, including $\mathrm{Cd}^{2+}, \mathrm{Fe}^{3+} / \mathrm{Fe}^{2+}, \mathrm{Mn}^{2+}, \mathrm{Ni}^{2+}, \mathrm{Co}^{2+}$ and $\mathrm{Cu}^{2+}$ (Grotz et al., 126 1998; Mäser et al., 2001, Eckhardt et al., 2001). Generally, the expression of ZIP genes is 127 upregulated when plants become Zn deficient (Ramesh et al., 2003; Ishimaru et al., 2006; Eide et 128 al., 1996), facilitating $\mathrm{Zn}$ influx to cells and movement of $\mathrm{Zn}$ between organs, and also when plants 129 become Fe or Mn deficient (Bughio et al., 2002; Vert et al., 2002; Ishimaru et al., 2006; Pedas et al., 130 2008). Other proteins that transport $\mathrm{Zn}$ include the Metal Tolerance Proteins (MTPs), which 131 function as cation/proton antiporters and are thought to transport $\mathrm{Zn}$ into vacuoles (Kolaj-Robin et 132 al., 2015) and the Yellow Stripe-Like Proteins (YSLs), which transport the Zn-Nicotianamine 133 complex (NA-Zn) and load Zn into the xylem and phloem (Curie et al., 2009). The Zinc Induced 134 Facilitators (ZIFs) and the Heavy Metal transporters (HMAs) are implicated in $\mathrm{Zn}$ influx to 135 vacuoles and to the xylem, respectively (Olsen and Palmgren, 2014). Zinc is chelated by organic 136 molecules, such as the carboxylic acid, citric acid, and nicotianamine (NA) in plants (Sinclair and 137 Krämer, 2012). Nicotianamine is a non-proteinogenic amino acid with a high affinity for $\mathrm{Fe}, \mathrm{Cu}$ and $138 \mathrm{Zn}$, and is involved in their homeostasis (Deinlein et al., 2012). Nicotianamine mediates the 139 intercellular and interorgan movement of $\mathrm{Zn}$ and was found to enable $\mathrm{Zn}$ hyperaccumulation in 140 Arabidopsis halleri and Noccaea caerulescens (Deinlein et al., 2012; Foroughi et al., 2014) In 141 general the functions of these transporters have been studied by expressing them in yeast, but to 142 understand how the various $\mathrm{Zn}$ transport proteins and chelates act together to maintain appropriate 143 cytosolic and tissue $\mathrm{Zn}$ concentrations it is important to study the responses of an intact plant to 
fluctuations in Zn supply.

In this study the transcriptional responses of genes encoding $\mathrm{Zn}$ transport-related processes facilitating $\mathrm{Zn}$ uptake by cells, vacuolar sequestration and redistribution within the plant were studied following foliar $\mathrm{Zn}$ application to the most productive and widely cultivated forage legume, alfalfa (Medicago sativa L.). The study was designed to provide information on the molecular responses to $\mathrm{Zn}$ biofortification of forage crops (Foyer et al., 2016; Capstaff and Miller, 2018). The following hypotheses were tested: i) foliar application of $\mathrm{Zn}$ increases shoot and root $\mathrm{Zn}$

151 concentrations, which results in changes in the expression of genes involved in $\mathrm{Zn}$ transport-related processes to detoxify excess $\mathrm{Zn}$; ii) genes encoding $\mathrm{Zn}$ transport-related processes are organized in functional modules, that act in a concerted manner to redistribute $\mathrm{Zn}$ within the plant to maintain non-toxic cytosolic and tissue $\mathrm{Zn}$ concentrations. Genes encoding putative $\mathrm{Zn}$ transport-related processes were identified in alfalfa through phylogenetic comparisons and their likely roles are discussed. Changes in the expression of these genes following foliar $\mathrm{Zn}$ application were determined and the possible effects of these on the redistribution of $\mathrm{Zn}$ within cells and between tissues are discussed. The knowledge gained from this study could help to optimize $\mathrm{Zn}$ biofortification strategies when using foliar $\mathrm{Zn}$ fertilisers and to provide strategies for breeding forage crops to addresses $\mathrm{Zn}$ deficiencies in livestock.

\section{RESULTS}

\section{Shoot and root $\mathrm{Zn}$ concentrations}

The application of $\mathrm{Zn}$ to leaves did not modify shoot or root biomass and all M. sativa plants had root nodules (data not shown). However, $\mathrm{Zn}$ concentrations in both shoots and roots were strongly affected by foliar $\mathrm{Zn}$ application $\left(\mathrm{F}_{(5,17)}=32.61, P<0.001 ; \mathrm{F}_{(5,17)}=28.53, \quad P<0.001\right.$; 
170 increased progressively by larger doses $\left(0.1<0.5 / 1<10 \mathrm{mg} \mathrm{Zn} \mathrm{plant}^{-1}\right)$, from more than threefold

171 to 35-fold more than that of the control (Fig. 1). Foliar applications of 0.01, 0.1 and $0.5 \mathrm{mg} \mathrm{Zn}$

172 plant $^{-1}$ did not produce root $\mathrm{Zn}$ concentrations greater than that of the control treatment, but foliar

173 doses of 1 and $10 \mathrm{mg} \mathrm{Zn} \mathrm{plant}^{-1}$ increased root $\mathrm{Zn}$ concentrations to threefold and 11-fold more than

174 the control treatment, respectively. Shoot and root Zn contents were also strongly affected by foliar 175 Zn application $\left(\mathrm{F}_{(5,17)}=53.73, P<0.001 ; \mathrm{F}_{(5,17)}=32.45, P<0.001\right.$; respectively $)$ and their responses to 176 increasing foliar $\mathrm{Zn}$ applications followed the corresponding $\mathrm{Zn}$ concentrations (Supplemental Fig. 177 S1).

\section{Phylogenetic analysis}

Phylogenetic analysis of the coding sequences of the ZIP genes revealed several distinct clades (Supplemental Fig S2). One clade contained sequences for MsZIP2 and MsZIP7, which were similar to each other. In addition, the sequence of MsZIP2 was closely related to those of MtZIP2 and GmZIP1-ZIP2 and the sequence of MsZIP7 was closely related to those of MtZIP7 and AtZIP11. Another clade contained the sequences of MsZIP1, MsZIP3, MsZIP5 and MsZIP6. The sequence of MsZIP1 clustered with that of MtZIP1. Sequences of MsZIP3 and MsZIP5 were similar to each other and clustered with the corresponding sequences for $M$. truncatula genes 187 (Supplemental Fig. S2). Sequences for MsZIP1, MsZIP3 and MsZIP5 were closely related to each other, whereas that of MsZIP6 formed a separate cluster with the sequences of MtZIP6 and AtZIP12. The sequence of MsZIP4 was distant from the sequences of other M. sativa ZIPs and formed a cluster with the sequences of MtZIP4 and AtZIP4.

Phylogenetic analyses of the coding sequences of the other genes related to $\mathrm{Zn}$ transport processes revealed that they were all similar to their $M$. truncatula counterparts. As regards ZIF, the sequence of MsZIF1 clustered with the sequences of MtZIF1 and GmZIF1 (Supplemental Fig. S3a). As regards $M T P$, the sequence of $M S M T P 1$ formed a cluster with MtMTP1 and GMMTP1 and was 
was most similar to those of MtYSL1 and GmYSL1 (Supplemental Fig. S3c) and the sequence of MsHMA4 was most similar to those of MtHMA4 and GmHMA4 (Supplemental Fig. S3d). Finally, the sequence of MsNAS1 was closely related to those of MtNAS and GmNAS (Supplemental Fig. S3e).

\section{Gene expression analysis}

The expression of MsZIP3 was significantly downregulated at foliar doses of $0.1,1$ and $10 \mathrm{mg}$ Zn plant $^{-1}\left(\mathrm{~F}_{(3,11)}=28.46, P<0.01\right)($ Fig. 2). By contrast, the expression of MsZIP2 was significantly upregulated at the largest dose of $10 \mathrm{mg} \mathrm{Zn} \mathrm{plant}^{-1}\left(\mathrm{~F}_{(3,11)}=5.59, P<0.05\right)$. The expression of MtZIP1, MtZIP5 and MtZIP6 in shoots was not significantly affected by foliar Zn application, although a general trend towards downregulation with increasing foliar $\mathrm{Zn}$ doses was observed. The expression of MsZIP4 and MsZIP7 in shoots was unaffected by foliar $\mathrm{Zn}$ application. The expression of $M s Z I P 2$ was significantly upregulated in roots at the largest foliar dose of $10 \mathrm{mg} \mathrm{Zn}$ plant $^{-1}\left(\mathrm{~F}_{(3,11)}=9.26, P<0.01\right.$ (Fig. 2). In roots, $Z I P$ genes were not significantly affected by foliar $\mathrm{Zn}$ application, although a general trend of MtZIP1, MtZIP3, MtZIP5 and MtZIP7 towards upregulation with increasing foliar $\mathrm{Zn}$ doses was observed. Of the other genes related to $\mathrm{Zn}$ transport processes, the expression of MsHMA4 was significantly upregulated in both shoots $\left(\mathrm{F}_{(3,11)}=115.29, P<0.01\right)$ 213 and roots $\left(\mathrm{F}_{(3,11)}=14.23, P<0.01\right)$ following the application of 1 and $10 \mathrm{mg} \mathrm{Zn} \mathrm{plant}{ }^{-1}$ (shoots: $214+63 \%$ and $+424 \%$, respectively; roots: $+86 \%$ and $+66 \%$, respectively; Fig. 3 ). In shoots, the expression of MsHMA4 was about 3-fold higher following a dose of $10 \mathrm{mg} \mathrm{Zn}$ plant $^{-1}$ than 216 following a dose of $1 \mathrm{mg} \mathrm{Zn}$ plant $^{-1}$, whereas the expression of MsHMA4 in roots was similar when 2171 or $10 \mathrm{mg} \mathrm{Zn} \mathrm{plant}^{-1}$ was applied. The expression of MsNAS1 was also significantly upregulated $218\left(\mathrm{~F}_{(3,11)}=6.46, P<0.05\right)$ at the largest foliar $\mathrm{Zn}$ dose $\left(10 \mathrm{mg}\right.$ plant $\left.{ }^{-1}\right)$, whereas its expression in roots 219 was unaltered following foliar Zn application (Fig. 3). In shoots, MsYSLI and MsZIF1 were not significantly affected by foliar $\mathrm{Zn}$ application, although there was a trend towards upregulation of 
following the application of $\mathrm{Zn}$ (Fig. 3). Finally, in roots, MsMTP1 and MsZIF1 were not significantly affected by foliar $\mathrm{Zn}$ application, although there was a trend towards upregulation of the expression with increasing $\mathrm{Zn}$ doses, whereas the expression of MsYSL1 remained unchanged (Fig. 3).

Using correlation analysis to reveal functional modules of genes whose expression is coregulated in plants, three functional modules for ZIP gene co-expression were observed (Fig. 4a; $r>$ 0.6). In the first functional module, the expression of MsZIP1, MsZIP3, MsZIP5 and MsZIP6 in shoots were all strongly correlated. Although the expression of MsZIP7 in shoots was also placed in this module, its expression was poorly correlated with the expression of other ZIP genes in either shoots or roots. The second functional module comprised correlations between the expression of MsZIP4 in shoots and roots, and the expression of MsZIP1, MsZIP3, MsZIP4, MsZIP5 and MsZIP6 in roots. The third functional module comprised correlations in the expression of MsZIP2 in shoots and roots and MsZIP7 in roots. With respect to the expression of the other genes involved in $\mathrm{Zn}$ transport related processes, there was a strong divergence in their expression patterns in shoots and roots (Fig. 4b). In the root, the expression of MsNAS1, MsYSL1, MsZIF1 and MsMTP1 were strongly correlated (Fig. 4b). The expression of MsYSL1, MsZIF1 and MsMTP1 in roots showed good correlations with the expression of $M S M T P 1$ and $M s Z I F 1$ in shoots. In the shoot the expression of MsYSL1, MsMTP1 and MsZIF1 were all strongly correlated. Also in shoots, the expression of MSNAS1 and MsHMA4 were well correlated and showed a good correlation with the expression of MsMTPI and MsZIF1 in shoots. Interestingly, the expression of MsNAS1 strongly correlated with that of MsYSL1 in shoots.

PERMANOVA showed that the expression of ZIP genes was significantly affected by foliar Zn application dose and differed between shoots and roots, which explained $29 \%$ and $23 \%$ of the total variance, respectively (Table 1). The expression of other genes related to $\mathrm{Zn}$ transport processes that were studied (MsZIF1, MsNAS1, MsHMA4, MsYSL1 and MsMTP1) were also affected by foliar Zn application dose and the organ examined. Zinc application dose explained $17 \%$ of the total variance, 
while plant organ explained 19\%. PERMANOVA on all studied genes highlighted a significant effect of $\mathrm{Zn}$ application dose, plant organ and their interaction on gene expression, explaining $68 \%$ of the total variance.

\section{DISCUSSION}

\section{Plant Zn nutritional status after foliar Zn application}

The critical leaf concentration for $\mathrm{Zn}$ deficiency approximates $15-20 \mu \mathrm{g} \mathrm{Zn} \mathrm{g}{ }^{-1}$ dry weight and the critical leaf concentration for $\mathrm{Zn}$ toxicity approximates $400-500 \mu \mathrm{g} \mathrm{Zn} \mathrm{g}{ }^{-1}$ (Broadley et al., 2012; White and Pongrac, 2017). Before foliar $\mathrm{Zn}$ application, the alfalfa plants used in the experiments reported here were probably $\mathrm{Zn}$ deficient, since their shoot $\mathrm{Zn}$ concentrations were below the critical leaf concentration for Zn deficiency (Fig. 1). After the application of the lowest foliar $\mathrm{Zn}$ dose $\left(0.01 \mathrm{mg}\right.$ plant $\left.^{-1}\right)$ plants probably remained $\mathrm{Zn}$ deficient (7.6 $\mu \mathrm{g} \mathrm{Zn} \mathrm{g}{ }^{-1}$ dry weight), but all other foliar $\mathrm{Zn}$ doses increased $\mathrm{Zn}$ concentrations in shoots above the critical concentration for $\mathrm{Zn}$ deficiency (Fig. 1). Plants treated with $0.1 \mathrm{mg} \mathrm{Zn} \mathrm{plant}{ }^{-1}$ probably had an optimal $\mathrm{Zn}$ status for plant growth, whereas plants treated with 0.5 and $1 \mathrm{mg} \mathrm{Zn}$ plant $^{-1}$ had shoot $\mathrm{Zn}$ concentrations close to the toxicity threshold. When a foliar dose of $10 \mathrm{mg} \mathrm{Zn} \mathrm{plant}^{-1}$ was applied, shoot $\mathrm{Zn}$ concentrations greatly exceeding the threshold for Zn toxicity (Fig. 1). Plants often exhibit characteristic visual symptoms of $\mathrm{Zn}$ deficiency and $\mathrm{Zn}$ toxicity when these occur (Broadley et al., 2012; White and Pongrac, 2017), but five days after foliar Zn application no visual symptoms of Zn deficiency or toxicity, nor differences in plant biomass, were observed among plants receiving 269 contrasting foliar $\mathrm{Zn}$ doses (data not shown). Foliar $\mathrm{Zn}$ doses larger than $0.1 \mathrm{mg} \mathrm{Zn}_{\text {plant }}{ }^{-1}$ resulted 270 in incremental increases in the $\mathrm{Zn}$ concentration of roots (Fig. 1), despite $\mathrm{Zn}$ having limited 271 mobility in the phloem (White and Broadley, 2011; White, 2012). This observation suggests that roots can act as a sink for $\mathrm{Zn}$ applied to leaves, thereby mitigating excessive $\mathrm{Zn}$ accumulation in 
phloem-fed tissues, such as fruits, seed, and tubers (Cakmak, 2004, 2008; Cakmak et al., 2010; White et al., 2017). The shoot to root $\mathrm{Zn}$ concentration ratio shifted from values below one in conditions of $\mathrm{Zn}$ deficiency (0.4) to values greater than one in $\mathrm{Zn}$-replete or $\mathrm{Zn}$-intoxicated plants

Zn deficient plants must be effectively redistributed within the plant (Erenoglou et al., 2011;

280 Sinclair and Kramer, 2012), whereas when excessive foliar $\mathrm{Zn}$ is applied, Zn must be chelated in 281 the cytoplasm, sequestered in the vacuole and redistributed via the phloem or xylem to other organs to avoid toxicity (White and Pongrac, 2017).

Foliar $\mathrm{Zn}$ application alters the expression of genes involved in $\mathrm{Zn}$ transport-related processes

Despite several genes encoding $\mathrm{Zn}$ transporters having been identified in plants, and the encoded proteins characterized, the mechanisms of $\mathrm{Zn}$ uptake and transport in alfalfa are still largely unknown. However, the recently sequenced alfalfa genome has allowed the discovery of genes involved in $\mathrm{Zn}$ uptake and distribution within this species (O'Rourke et al., 2015). In the present study, 12 putative genes encoding proteins likely to be involved in processes related to $\mathrm{Zn}$ transport in the plant $\left(M s Z I P_{1-7}, M s Z I P 1, M s M T P 1, M s Y S L 1, M s H M A 4\right.$ and MsNAS1) were identified and their expression in shoots and roots quantified following foliar $\mathrm{Zn}$ applications (Fig. sequestration and redistribution within the plant responded differently to increasing foliar $\mathrm{Zn}$ dose. The expression of MsZIP2, MsHMA4 and MsNAS1 in shoots was increased by increasing foliar $\mathrm{Zn}$ dose, while only the expression of $M s Z I P 2$ and $M s H M A 4$ in roots were upregulated by increasing foliar Zn dose (Fig. 2; Fig. 3). By contrast, MsZIP3 was downregulated in shoots when foliar Zn doses $\geq 0.1 \mathrm{mg} \mathrm{Zn} \mathrm{plant}^{-1}$ were applied (Fig. 2). These changes in gene expression might produce a 
300 influx through MsZIP3 and increasing Zn efflux through MsHMA4), chelation of Zn using Zn-NA

301 in the shoot for $\mathrm{Zn}$-detoxification and phloem transport, and greater recirculation of $\mathrm{Zn}$ within the 302 plant in both the phloem and xylem (by increasing NA concentrations and MsZIP2 and MsHMA4 303 activities), and are, therefore, consistent with the observation that increasing foliar $\mathrm{Zn}$ dose 304 increases both shoot and root $\mathrm{Zn}$ concentrations.

\section{Regulation of genes encoding ZIP transporters}

The influx and efflux of $\mathrm{Zn}$ across the plasma membrane of plant cells must be tightly controlled to allow optimal cell functioning and hence to ensure normal plant growth and development (Sinclair and Krämer, 2012). The expression of only two of the seven ZIP genes studied, MsZIP2 and MsZIP3, showed statistically significant responses to foliar Zn application

311 (Fig. 2). The expression of $M s Z I P 2$ was significantly upregulated in both shoots and roots in response to the largest dose of foliar $\mathrm{Zn}$ applied (10 $\left.\mathrm{mg} \mathrm{Zn} \mathrm{plant}^{-1}\right)$. It is likely that this dose is toxic to both shoot and root cells. The relative induction in the expression of MsZIP2 was greatest in roots. The phylogenetic analysis of ZIP transporters revealed that MsZIP2 is closely related to MtZIP2 and AtZIP2 (Supplemental Fig. S6). Thus, MsZIP2 is probably located in the plasma membrane performing similar functions to MtZIP2 and AtZIP2. Burleigh et al. (2003) reported that M. truncatula plants grown with adequate soil $\mathrm{Zn}$ availability expressed MtZIP2 in roots and stems, but not in leaves. The expression of MtZIP2 in roots increased with increasing $\mathrm{Zn}$ fertiliser applications to soil, with the greatest expression being found at toxic $\mathrm{Zn}$ doses (Burleigh et al., 2003). Similarly, Milner et al. (2013) found that the expression of AtZIP2 was $\sim 10$-fold higher in roots than shoots in $\mathrm{Zn}$-replete Arabidopsis thaliana plants and that $\mathrm{Zn}$ deficiency reduced the expression of AtZIP2 in both roots and shoots. The localization of ZIP2 at the plasma membrane was observed in both M. truncatula (Burleigh et al., 2003) and A. thaliana (Milner et al., 2013). The expression of AtZIP2 was localized to the stele of the root (Milner et al., 2013), supporting a role of 
expression of MsZIP2 observed in our study when plants experience $\mathrm{Zn}$ toxicity might be a detoxification strategy, either through storing excess $\mathrm{Zn}$ in xylem parenchyma cells or recirculating $\mathrm{Zn}$ in the xylem.

The expression of MsZIP3 was significantly downregulated in shoots following the foliar application of $\mathrm{Zn}$ (Fig. 2). The ZIP3 transporter is thought to mediate $\mathrm{Zn}$ influx to the cell from the apoplast (Sinclair and Kramer, 2012). Therefore, the downregulation of MsZIP3 in shoots of plants receiving more $\mathrm{Zn}$ is consistent with the ability of plant cells to control their $\mathrm{Zn}$ uptake to effect cytoplasmic $\mathrm{Zn}$ homeostasis. Reduced expression of $M s Z I P 3$ in plants with a greater $\mathrm{Zn}$ supply is also in agreement with previous studies of M. truncatula and A. thaliana (Grotz et al., 1998; LopézMillán et al., 2004). However, although AtZIP3 could restore growth to a Zn-uptake defective yeast (Milner et al., 2013), MtZIP3 was not found to be able to restore the growth of a Zn-uptake defective yeast in Zn-limited media, although it did restore the growth of a Fe-uptake defective yeast in Fe-limited media (López-Millán et al., 2004). Thus, the MsZIP3 transporter could have a higher affinity for Fe than $\mathrm{Zn}$. In O. sativa ZIP3 gene is expressed in the xylem parenchyma and transfer cells and might be responsible for unloading transition metal cations from the xylem to the parenchyma in plants receiving an excessive Zn supply (Sasaki et al., 2015). The role of OsZIP3 in unloading $\mathrm{Zn}$ from the vascular tissues, suggests that the reduced expression of MsZIP3 in shoots of M. sativa receiving an excessive foliar $\mathrm{Zn}$ dose might be a detoxification strategy to reduce $\mathrm{Zn}$ uptake by shoot cells.

The observation that foliar $\mathrm{Zn}$ applications had no effect on the expression of ZIP genes, except MsZIP2 and MsZIP3 (Fig. 2), might be explained by the roles of ZIP proteins in the transport of other transition metals. For example, evidence of $\mathrm{Cu}$ and $\mathrm{Mn}$ transport by ZIP4 were provided through yeast complementation studies (Wintz et al., 2003; López-Millán et al., 2004). Moreover, applying the same technique, a role of ZIP6 was highlighted in the transport of Fe by López-Millán et al. (2004), whereas Wintz et al. (2003) did not find any involvement of ZIP6 in the transport of $\mathrm{Cu}, \mathrm{Zn}$ or Fe. Although the changes in the expression of MsZIP1, MsZIP5 and MsZIP6 following 
foliar $\mathrm{Zn}$ application were not statistically significant, changes in their expression in shoots were positively correlated with changes in the expression of $M s Z I P 3$, showing a general trend for them to be downregulated following foliar $\mathrm{Zn}$ application and suggesting that these four ZIPs might act as a functional module in the shoot (Fig. 4). By contrast, the expression of MsZIP1, MsZIP3, MSZIP4, and MsZIP5 were positively correlated in roots, suggesting that these genes behave as a functional module in roots (Fig. 4).

\section{Regulation of genes encoding other Zn transport-related processes}

The expression of MsHMA4, which is implicated in $\mathrm{Zn}$ redistribution within the plant (Hussain

et al., 2004; Sinclair et al., 2018), was increased in both shoots and roots of plants whose shoot $\mathrm{Zn}$ concentration suggested they were close to, or experiencing, $\mathrm{Zn}$ toxicity (Fig. 3). The significant upregulation of MsHMA4 following foliar application of $\geq 1 \mathrm{mg} \mathrm{Zn} \mathrm{plant}^{-1}$ might be related to the removal of excess $\mathrm{Zn}$ from both shoots and roots. This interpretation is consistent with the role of HMA4 in A. thaliana and in the metal hyperaccumulators Arabidopsis halleri and Noccea caerulescens (Baker and Whiting, 2002; Hussain et al., 2004; Hanikenne et al., 2008; Ò Lochlainn et al., 2011; White and Pongrac, 2017), in which greater expression of HMA4 results in greater $\mathrm{Zn}$ flux to the xylem and $\mathrm{Zn}$ translocation to transpiring leaves. However, the phylogenetic similarity of MsHMA4 to MtHMA4 and, particularly, to AtHMA5 (Supplemental Fig. S3d) suggest a role in $\mathrm{Cu}$ transport (Andrés-Colás et al., 2006; Sankaran et al., 2009; Hermand et al., 2014). This implication of the latter observation is unclear.

Since $\mathrm{Zn}^{2+}$ concentrations are low in the alkaline phloem sap, the transport of most $\mathrm{Zn}$ in the phloem is as $\mathrm{Zn}$ ligand complexes, such as zinc-nicotianamine (NA-Zn) (Deshpande et al., 2018).

374 Nicotianamine is the main $\mathrm{Zn}$ chelate in phloem transport and is also important for $\mathrm{Zn}$ sequestration in vacuoles (Deinlein et al., 2012), and tolerance of excessive Zn uptake (Aarts et al., 2014). 
Accordingly, in the work reported here the increased expression of MsNAS1 in shoots following the application of $\geq 1 \mathrm{mg} \mathrm{Zn} \mathrm{plant}{ }^{-1}$ (Fig. 3) probably reflects the role of NA in $\mathrm{Zn}$ detoxification through its sequestration within vacuoles and its redistribution from shoot to root after excessive foliar Zn applications. This observation is consistent with Deshpande et al. (2018), who found that the expression of NAS2 in the durum wheat (Triticum durum Desf.) increased following foliar $\mathrm{Zn}$ application and reports that $N A S$ expression is constitutively high in plants that hyperaccumulate $\mathrm{Zn}$ (Becher et al., 2004; Weber et al., 2004; Haydon et al., 2012; White and Pongrac, 2017).

Homologs of MsMTP1 and MsZIF1 were previously found to encode transporters loading $\mathrm{Zn}$ and NA into the vacuoles of Thlaspi geosingense and A. thaliana cells, respectively (Gustin et al., 2009; Haydon et al., 2012). Unexpectedly, the expression of these genes was unaffected by foliar Zn application (Fig. 3). This observation suggests that the proteins encoded by these genes might not contribute to $\mathrm{Zn}$ detoxification in $M$. sativa. Nevertheless, only MsZIF1 of all the genes studied here showed a trend towards increased expression in roots with increasing foliar Zn dose (Fig. 3), which might indicate a role in detoxification of excess $\mathrm{Zn}$ in roots through its sequestration with NA in the vacuole. The high correlation between the expression of MsMTPI and MsZIF1 in both shoots and roots suggests that they might constitute a functional module and act synergistically to sequester $\mathrm{Zn}$ in the vacuole (Fig. 4), as supported by other studies (Gustin et al., 2009; Haydon et al., 2012; Sharma et al., 2016).

In A. thaliana, AtYSL1 has a role in the long-distance transport of the NA-Zn complex and in loading Zn into seeds (Jean et al., 2005; Curie et al., 2009). For this reason, an increase in the expression of MtYSL1 was expected to occur in parallel with the increased expression of MsNAS1 in shoots. However, the expression of MSYSL1 did not show any significant change in shoots or roots 400 in response to foliar $\mathrm{Zn}$ application, although there was a trend towards greater MsYSL1 expression 401 in shoots with increasing foliar Zn doses (Fig. 3). In addition, the high correlation in the expression of MSNAS1 and MSYSL1 in shoots in response to foliar Zn applications (Fig. 4) supports the 
404 transport of $\mathrm{Zn}$ in the plant, as it was previously highlighted in A. thaliana by Pita-Barbosa et al. 405 (2019).

406 The responses of gene expression to foliar $\mathrm{Zn}$ applications suggest three functional modules 407 that effect cytoplasmic $\mathrm{Zn}$ homeostasis through $\mathrm{Zn}$ transport related processes in $M$. sativa: genes 408 involved in Zn influx to cells (shoots: MsZIP1, MsZIP5, and MsZIP6; roots: MsZIP1, MSZIP4, 409 MsZIP5, and MsZIP6), genes involved in $\mathrm{Zn}$ sequestration in the vacuole (shoots and roots: $410 M s M T P 1$ and MsZIF1) and genes involved in Zn redistribution within the plant (shoots and roots: 411 MsHMA4 and MsYSL1).

412 In conclusion, this is the first study to characterise the expression of genes related to $\mathrm{Zn}$ 413 transport processes following foliar $\mathrm{Zn}$ application to a forage legume and provides new molecular 414 insights to the responses of $\mathrm{Zn}$ transport related processes to foliar $\mathrm{Zn}$ applications. A significant 415 increase in the expression of $M s Z I P 2$ as foliar $\mathrm{Zn}$ doses increase suggests the detoxification of 416 excess $\mathrm{Zn}$ through the accumulation of $\mathrm{Zn}$ in xylem parenchyma cells. A decrease in the expression 417 of $M s Z I P 3$ as foliar $\mathrm{Zn}$ doses increase suggests a reduction in the $\mathrm{Zn}$ influx capacity of shoot cells 418 to reduce $\mathrm{Zn}$ uptake. An increase in the expression of MsHMA4 in roots and shoots as foliar $\mathrm{Zn}$ 419 doses increase suggests an increase in the transport of $\mathrm{Zn}$ in the xylem when plants are subject to $\mathrm{Zn}$ 420 toxicity, while an increase in the expression of MsNAS1 in the shoot suggests the chelation of 421 excess $\mathrm{Zn}$ in the shoot, enabling $\mathrm{Zn}$ sequestration in vacuoles or the redistribution of $\mathrm{Zn}$ to roots via 422 the phloem. The elucidation of three functional modules of genes involved in (a) Zn influx to cells, 423 (b) sequestration of $\mathrm{Zn}$ in the vacuole and (c) redistribution of $\mathrm{Zn}$ within the plant are fundamental 424 to understanding the molecular mechanisms of cytoplasmic $\mathrm{Zn}$ homeostasis and might inform the 425 selection of appropriate genotypes enabling greater $\mathrm{Zn}$ accumulation in edible portions or increased 426 tolerance of $\mathrm{Zn}$ in the environment. 


\section{Plant growth and experimental design}

Surface sterilized seeds of alfalfa ( $M$. sativa L.) were germinated on moist sterilized silica sand 432 (1-4 mm size) in a climatic chamber at $24 / 21^{\circ} \mathrm{C}$ day/night temperature, $16 / 18 \mathrm{~h} \mathrm{light/dark}$ cycle and $433200 \mu \mathrm{mol}$ photons $\mathrm{m}^{-2} \mathrm{~s}^{-1}$. After two weeks of growth, three seedlings were transplanted to $1500 \mathrm{~mL}$ volume pots, filled with sterilized silica sand (number of pots 18) and Sinorhizobium meliloti was supplied as a filtrate to all plants to ensure that the plants produced nodules in all treatments. A Hoagland nutrient solution lacking $\mathrm{Zn}$ (Li et al., 2013) was used to fertilize the plants, with $10 \mathrm{~mL}$ solution being applied every week. After two months of growth, plants were treated with one of six doses of $\mathrm{Zn}\left(0,0.01,0.1,0.5,1\right.$ and $10 \mathrm{mg} \mathrm{Zn} \mathrm{plant}^{-1}$ ) (three replicates per dose). Six $\mathrm{ZnSO}_{4} \cdot 7 \mathrm{H}_{2} \mathrm{O}$

Zn uptake. Zinc was applied to the middle leaf laminae of the three plants in each pot as twenty 10 $\mu 1$-droplets. The experiment was arranged in a fully randomized design, with three replicates for each $\mathrm{Zn}$ dose. The shoots and roots of the plants were harvested separately five days after $\mathrm{Zn}$ application. At harvest, $1 \mathrm{mM} \mathrm{CaCl}$ solution and water were used to remove any residual $\mathrm{Zn}$ from the leaf surface (Yilmaz et al., 2017). Shoot and root fresh weight was measured, whereas shoot and root dry weight was determined on subsamples after oven drying at $70^{\circ} \mathrm{C}$ to constant weight.

\section{Measurement of zinc concentrations}

Approximately $100 \mathrm{mg}$ of shoot or root dry biomass were carefully weighed and mineralized in a microwave medium pressure digestor (Milestone Start D, FKV Srl, Torre Boldone, Italy) with 7 $\mathrm{mL}$ of $69 \% \mathrm{HNO}_{3}$ and $2 \mathrm{~mL}$ of $30 \% \mathrm{H}_{2} \mathrm{O}_{2}$ (ultrapure grade). Zinc concentration in the resulting solutions was determined by inductively coupled plasma optical emission spectroscopy (ICP-OES) of Nölte (2003). 


\section{Gene selection and design and validation of new RT-qPCR assay}

Seven genes encoding putative ZRT-IRT-like proteins (ZIP) were selected for investigation

458 (i.e., ZIP1-7) (Fig. 5). The selection was based on information gathered by Burleigh et al. (2003)

and López-Millán et al. (2004) on the expression of genes encoding Zn transporters in the model

legume Medicago truncatula and on the structure of the neighbor joining (NJ) tree built using

available ZIP sequences of several plant species. Five more genes, whose products are involved in

$462 \mathrm{Zn}$ transport-related processes (Olsen and Palmgren, 2014), were also chosen for investigation

463 based on information gathered by other authors and on sequence similarity with other plant species.

464 The NAS1 gene encoding nicotianamine synthase (NAS) was chosen because this enzyme 465 synthesizes nicotianamine (NA), which is involved in long-distance $\mathrm{Zn}$ transport (Curie et al., 2009)

466 (Fig. 5). The HMA4 gene, which encodes a transmembrane P-type ATPase heavy metal transporter, 467 was chosen because this transporter loads $\mathrm{Zn}$ into the xylem in roots for its transport to shoots 468 (Palmer and Guerinot, 2009) (Fig. 5). The MTP1 gene, which encodes a transporter of the CDF 469 family, was selected because this transporter is implicated in the sequestration of excess $\mathrm{Zn}$ in the 470 vacuole (Desbrosses-Fonrouge et al., 2005; Gustin et al., 2009) (Fig. 5). The ZIF1 gene, which 471 encodes the Zn-induced facilitator 1 transporter, was chosen because it transports NA into the 472 vacuole to chelate vacuolar Zn (Haydon and Cobbett, 2007; Haydon et al., 2012) (Fig. 5). The YSL1 473 gene, which encodes a transporter of Zn-NA complexes, was chosen because it is implicated in $\mathrm{Zn}$ loading and transport of $\mathrm{Zn}$ in the phloem (Palmer and Guerinot, 2009) (Fig. 5). To standardize the expression of genes encoding $\mathrm{Zn}$ transport-related processes, two reference genes were selected: actin $(A C T)$ and elongation factor 1- $\alpha(E F 1-\alpha)$ (Nicot et al., 2005).

Using the draft genome sequence of alfalfa in the Alfalfa Gene Index and Expression Atlas 
two reference genes were named MsACT-101 and MsEF1- $\alpha$. The gene sequences and their annotations have been deposited in NCBI under the Submission \# 2338923.

Forward and reverse new PCR primers for the $12 \mathrm{Zn}$ transport-related genes and the two reference genes suitable for $\mathrm{SYBR}^{\circledR}$ Green II RT-qPCR assays (Biorad, USA) were designed (Table

2). The Primer-BLAST online tool in the National Center for Biotechnology Information (NCBI;

487 https://www.ncbi.nlm.nih.gov/tools/primer-blast/) was used to design primers. The newly designed RT-qPCR assays are suitable for both $M$. sativa and $M$. truncatula. The length of the fragment, the Sanger sequences of the PCR amplicons (Table 2) and the single melting temperature peaks confirmed the specificity of the new RT-qPCR assays (Supplemental Fig. S4). Sanger sequencing was performed on PCR amplicons of three cDNA samples (Supplemental Material and Methods S1). Examples of electropherograms of the sequences are reported in Supplemental Fig. S5. The sequences of the obtained PCR amplicons have been deposited in NCBI the Submission \# 2338930. Amplification efficiencies (E) in the range of 96.1-111.0\% are evidence of accurate quantification, while the coefficients of correlation $\left(\mathrm{R}^{2}>0.998\right)$ indicate high precision of measurements across concentration ranges of at least 3-4 orders of magnitude (Table 2; Supplemental Fig. S6). The concentration ranges over which the relationship between the relative fluorescence and the logarithm of the concentration is linear, and the precision of quantification (standard curves) as reflected in the coefficient of correlation $\left(\mathrm{R}^{2}\right)$, were determined using three independent 10 -fold serial dilutions of a cDNA sample of $M$. sativa. The accuracy of quantification was determined by 501 the efficiency (E) of each qPCR amplification, using the equation $E=\left[10^{-1 / \mathrm{S}}-1\right] \times 100$, where $\mathrm{S}$ is 502 the slope of the standard curve. The evaluation of the reference genes based on the cycle threshold 503 (Ct) values made us choose the actin gene (MSACT-101) for quantifying relative gene expression in 504 the shoots and the elongation factor $1-\alpha(M s E F 1-\alpha)$ gene for quantifying relative gene expression in 505 roots (Supplemental Fig. S7a,b). This choice was based on the observations that there was no statistical difference in the expression of the reference genes in tissues following foliar $\mathrm{Zn}$ 
applications and that MsACT-101 and MsEF1- $\alpha$ showed the smallest overall variation in the shoot and root, respectively (Supplemental Fig. S7c,d).

\section{RNA extraction and gene expression analysis}

Total RNA was extracted from $50 \mathrm{mg}$ subsamples of fresh shoot and root tissue, using the

RNeasy Mini Kit (Qiagen, Hilden, Germany). The extractions were performed from tissues of plants treated with the foliar $\mathrm{Zn}$ doses that produced a significant increase in $\mathrm{Zn}$ concentration in shoots $\left(0.1,1\right.$ and $\left.10 \mathrm{mg} \mathrm{Zn} \mathrm{plant}^{-1}\right)$ and the control plants to which no foliar $\mathrm{Zn}$ had been applied (24 RNA extractions). Any DNA in the RNA extracts was removed by a DNase treatment (Promega, USA). The purity of the RNA extracts was verified by spectroscopic light absorbance measurements at $230 \mathrm{~nm}, 260 \mathrm{~nm}$ and $280 \mathrm{~nm}$ using the NanoDrop 2000 (Termo Scientific, Worchesre, MA, USA) (Desjardins and Conkin, 2010). The integrity and approximate concentration of the extracted RNA was determined by electrophoresis of the RNA extracts in a $1 \%$ agarose gel containing Sybr Safe (Invitrogen, Carlsbad, CA). One microgram of total RNA was reverse transcribed to complementary DNA (cDNA) using the iScript cDNA Synthesis Kit (Biorad, Hercules, California) in a $20 \mu \mathrm{L}$ reaction volume. The RT-qPCRs for gene expression analysis were run as three technical replicates with a final reaction volume of $20 \mu \mathrm{L}$, containing $10 \mu \mathrm{L}$ of SYBR gene-specific PCR primers on a CFX Connect Real-Time System thermal cycler (Biorad, Hercules, California). The qPCR conditions were $95^{\circ} \mathrm{C}$ for $3^{\prime}$, followed by 40 cycles of $95^{\circ} \mathrm{C}$ for $5^{\prime}$, and $60^{\circ}$ $\mathrm{C}$ for 30'. A dissociation curve of each reaction was performed $\left(65^{\circ} \mathrm{C}\right.$ to $95^{\circ} \mathrm{C}, 0.5^{\circ} \mathrm{C}$ increment every 5') to check that PCR amplified only one product. The most suitable reference gene for relative gene expression analysis was determined by comparing the expression levels of the reference genes $M s A C T-101$ and $M s E F 1-\alpha$ across all cDNA samples. Relative gene expression was 531 calculated using the double standardisation $(\Delta \Delta \mathrm{Cq})$ method that requires a reference gene and a 


\section{Bioinformatic and statistical analyses}

A BLAST search was performed in the Alfalfa Gene Index and Expression Atlas database using

allowed the identification of gene sequences encoding potential metal transporters and chelators in the whole $M$. sativa genome. The sequences obtained were aligned with the corresponding sequences from $M$. truncatula and the length of the $M$. sativa genes were determined after removing the external unaligned nucleotides. The $M$. sativa and $M$. truncatula ZIP gene sequences were also aestivum, and Zea mays) obtained from a search of GenBank. Similarly, the M. sativa and $M$. truncatula gene sequences of ZIF1, MTP1, YSL1, HMA4 and NAS were aligned with their corresponding sequences of other plant species (A. thaliana, G. max, H. vulgare, O. sativa, T. aestivum, and Z. mays) obtained from a search of GenBank. Sequence alignments were performed using the algorithm ClustalW in MEGA X (Kumar et al., 2018). Phylogenetic comparisons were performed to infer the putative roles of the selected $M$. sativa $\mathrm{Zn}$ transport-related proteins. The phylogenetic trees were inferred by Neighbor-Joining (NJ) analysis (Saitou et al., 1987) in MEGA

$550 \mathrm{X}$ and the evolutionary distances were calculated using the p-distance method (Nei and Kumar, 551 2000). Branch support bootstrap values were derived from 500 bootstrap replicates. The phylograms were drawn by MEGA X and edited using Adobe Illustrator CC 2017. of the selected genes was analysed in shoots and roots separately by one-way analysis of variance 555 (ANOVA), followed by a Tukey-B test in the case of significance of the response to foliar $\mathrm{Zn}$ application. When required, gene expression data were log-transformed to meet the ANOVA assumptions. The data displayed graphically are the means and associated standard errors of the 
version 21.0 (SPSS Inc., Chicago, IL, USA). Permutational analysis of variance (PERMANOVA;

560 Anderson, 2001) was used to test the effect of foliar $\mathrm{Zn}$ application and plant organ (shoot and root)

561 on the expression of the seven ZIP genes and of the other five genes encoding Zn transport-related 562 processes separately. In addition, the PERMANOVA was performed on the expression of all the 563 genes together. The response data matrices were standardised by sample, and total and then 564 Euclidean distances were calculated among samples. $P$-values were calculated using the Monte565 Carlo test (Anderson and Braak, 2003). Since PERMANOVA is sensitive to differences in 566 multivariate location and dispersion, analysis of homogeneity of multivariate dispersion 567 (PERMDISP; Anderson, 2006) was performed to check the homogeneity of dispersion among 568 groups. The analyses were performed using PRIMER 7 and PERMANOVA+ software (Clarke and 569 Gorley, 2015). Finally, heatmaps were constructed to illustrate correlations in expression among 570 ZIPs and among other genes encoding $\mathrm{Zn}$ transport-related processes using the $\mathrm{R}$ package ggplot2 571 (Wickham, 2011), using the average linkage clustering of the Pearson correlations calculated from relative gene expression following foliar $\mathrm{Zn}$ application.

\section{Supplemental Materials}

Supplemental Figure S1. Shoot and root zinc ( $\mathrm{Zn}$ ) content of alfalfa (Medicago sativa L.) five days after application of six doses of $\mathrm{Zn}$ to leaves.

Supplemental Figure S2. Neighbor-Joining phylogenetic tree of ZIP gene sequences of Medicago sativa, Medicago truncatula and other plant species.

Supplemental Figure S3. Neighbor-Joining phylogenetic trees of sequences of Zinc Induced 
585 Transporter (HMA) and Nicotianamine Synthase (NAS) genes of Medicago sativa, Medicago 586 truncatula and other plant species.

588 Supplemental Figure S4. Melting curve analysis of the qPCR products obtained by the newly 589 designed pair of primers.

591 Supplemental Figure S5. Electropherograms of PCR products obtained by the newly designed primers for $M s Z I P_{1-7}$ transporters and for other $\mathrm{Zn}$ related genes.

SupplementalFigure S6. Standard curves for the newly designed qPCR primer pairs.

Supplemental Figure S7. Cycle threshold value of the reference genes, actin 101 (MsACT-101) and elongation factor 1- $\alpha(M s E F f 1-\alpha)$ in shoots and roots for the no-Zn addition control and the three $\mathrm{Zn}$ doses.

Supplemental Material and Methods S1. PCR amplification conditions.

\section{ACKNOWLEDGEMENTS}

We acknowledge the Italian Institute of Technology (IIT) for funding for PhD Fellowship of

$\mathrm{AC}$ under the $\mathrm{PhD}$ programme in Agrobiosciences at the Scuola Superiore Sant'Anna of Pisa, Italy. support in real-time RT-PCR. 
Table 1 Permutation analyses of variance (PERMANOVAs) on the effect of application of three doses of zinc $(\mathrm{Zn})\left(0.1,1\right.$ and $\left.10 \mathrm{mg} \mathrm{Zn} \mathrm{plant}^{-1}\right)$ and plant compartment (shoot and root) on the expression of seven MsZIP genes and separately on the expression of other five genes (MsZIF1, MsNAS1, MsHMA4, MsYSL1 and MsMTP1) (see Table 1, Fig. 1). A PERMANOVA was also performed on the response of all the genes. The analysis of homogeneity of multivariate dispersion (PERMDISP) was also performed. The studied plant was alfalfa (Medicago sativa L.). The analysis included also no-Zn addition control. Gene relative expression was studied on a total of 24 experimental units, corresponding to three replicates per each level of treatment.

\begin{tabular}{|c|c|c|c|c|c|}
\hline $\begin{array}{l}\text { Response } \\
\text { variables }\end{array}$ & $\begin{array}{l}\text { Explanatory } \\
\text { variables }\end{array}$ & $\begin{array}{c}\text { Zn application } \\
\text { (Zn) }\end{array}$ & $\begin{array}{c}\text { Plant } \\
\text { compartment } \\
\text { (Comp) }\end{array}$ & Zn x Comp & Residual \\
\hline \multirow{4}{*}{ ZIP genes } & Pseudo F & 5.56 & 8.16 & 1.76 & \multirow{4}{*}{38.3} \\
\hline & $P($ perm $)$ & 0.002 & 0.001 & 0.082 & \\
\hline & $\begin{array}{l}\text { Explained } \\
\text { variance }(\%)\end{array}$ & 29.1 & 22.9 & 9.7 & \\
\hline & $\begin{array}{l}\text { PERMDISP } \\
P(\text { perm })\end{array}$ & 0.005 & 0.766 & & \\
\hline \multirow{4}{*}{ Other genes } & Pseudo F & 3.06 & 5.59 & 1.76 & \multirow{4}{*}{50.55} \\
\hline & $P($ perm $)$ & 0.007 & 0.015 & 0.1 & \\
\hline & $\begin{array}{l}\text { Explained } \\
\text { variance }(\%)\end{array}$ & 17.3 & 19.35 & 12.78 & \\
\hline & $\begin{array}{l}\text { PERMDISP } \\
P(\text { perm })\end{array}$ & 0.412 & 0.852 & & \\
\hline \multirow{4}{*}{ All genes } & Pseudo F & 4.27 & 10.49 & 3.41 & \multirow{4}{*}{31.9} \\
\hline & $P($ perm $)$ & 0.001 & 0.001 & 0.003 & \\
\hline & $\begin{array}{l}\text { Explained } \\
\text { variance }(\%)\end{array}$ & 17.3 & 25.2 & 25.6 & \\
\hline & $\begin{array}{l}\text { PERMDISP } \\
P(\text { perm })\end{array}$ & 0.152 & 0.030 & & \\
\hline
\end{tabular}


Table 2 Gene name, forward and reverse sequences of fourteen newly designed primer pairs for the quantification of the expression of genes of alfalfa (Medicago sativa), encoding proteins involved in cellular zinc ( $\mathrm{Zn}$ ) influx and efflux and $\mathrm{Zn}$ chelation (see Fig. 1). Two reference genes (i.e., MsACT-101 and MsEF1- $\square \square \square$ were also designed. The length of the amplicons, the primer amplification Efficiency $(\%)$ and $\mathrm{R}^{2}$ of the standard curve are indicated (see Fig. S3). The reference sequences are indicated by the accession number of the Medicago truncatula sequences and by the contig number of the $M$. sativa sequences. The primers were designed using the National Center for Biotechnology Information PRIMER Blast online tool.

\begin{tabular}{|c|c|c|c|c|c|c|}
\hline Gene* & $\begin{array}{l}\text { Reference } \\
\text { sequence } \\
\text { (Accession } \\
\text { number and } \\
\text { contig } \\
\text { number) }\end{array}$ & $\begin{array}{l}\text { Forward primer } \\
\left(5^{\prime}-3^{\prime}\right)\end{array}$ & $\begin{array}{l}\text { Reverse primer } \\
\left(5^{\prime}-3^{\prime}\right)\end{array}$ & $\begin{array}{l}\text { Amplicon } \\
\text { size (bp) }\end{array}$ & $\begin{array}{l}\text { Efficiency } \\
(\%)\end{array}$ & $\mathbf{R}^{2}$ \\
\hline MsZIP1 & $\begin{array}{l}\text { AY339054 } \\
19855^{\ddagger}\end{array}$ & $\begin{array}{l}\text { ATGATTAAAGCCT } \\
\text { TCGCGGC }\end{array}$ & $\begin{array}{l}\text { TCTGCTGGAACTT } \\
\text { GTTTAGAAGG }\end{array}$ & 233 & 99.8 & 0.999 \\
\hline$M s Z I P 2$ & $\begin{array}{l}\text { AY007281/8 } \\
2450\end{array}$ & $\begin{array}{l}\text { AGCCCAATTGGCG } \\
\text { TAGGAAT }\end{array}$ & $\begin{array}{l}\text { ACAGCAACACCAA } \\
\text { AAAGCACA }\end{array}$ & 215 & 99.3 & 0.999 \\
\hline MsZIP3 & $\begin{array}{l}\text { AY339055/3 } \\
3860\end{array}$ & $\begin{array}{l}\text { TGGTGTGATTTTG } \\
\text { GCAACCG }\end{array}$ & $\begin{array}{l}\text { TGACGGACCCGAA } \\
\text { GAAACAG }\end{array}$ & 325 & 104.9 & 0.999 \\
\hline MsZIP4 & $\begin{array}{l}\text { XM_003603 } \\
101 / 92651\end{array}$ & $\begin{array}{l}\text { GGAGGGTGCATTT } \\
\text { CTCAAGC }\end{array}$ & $\begin{array}{l}\text { AGCAATGCCTGTT } \\
\text { CCAATGC }\end{array}$ & 108 & 97.1 & 0.999 \\
\hline MsZIP5 & $\begin{array}{l}\text { XM_013605 } \\
712 / 66451\end{array}$ & $\begin{array}{l}\text { TGAAGGCATGGG } \\
\text { ACTTGGAA }\end{array}$ & $\begin{array}{l}\text { CCAGCTGAAGCTG } \\
\text { CATTGAA }\end{array}$ & 192 & 99.3 & 0.998 \\
\hline MsZIPG & $\begin{array}{l}\text { AY339058/9 } \\
668\end{array}$ & $\begin{array}{l}\text { CTTGGCGACACGT } \\
\text { TCAATCC }\end{array}$ & $\begin{array}{l}\text { CCACAAGTCCCGA } \\
\text { AAAGGGA }\end{array}$ & 188 & 106.0 & 0.998 \\
\hline MsZIP7 & $\begin{array}{l}\text { AY339059/6 } \\
2098\end{array}$ & $\begin{array}{l}\text { GGCTTGTGCTGGT } \\
\text { TATTTGAT }\end{array}$ & $\begin{array}{l}\text { TTTCCATGCGTCT } \\
\text { GCTTTTGT }\end{array}$ & 310 & 96.1 & 0.999 \\
\hline MsZIF1 & $\begin{array}{l}\text { XM_003601 } \\
836 / 59165\end{array}$ & $\begin{array}{l}\text { TGCCTGCATTTGG } \\
\text { TTACCG }\end{array}$ & $\begin{array}{l}\text { CTGCAGCTTCCAC } \\
\text { ATTGTCAG }\end{array}$ & 77 & 105.9 & 0.999 \\
\hline MsHMA4 & $\begin{array}{l}\text { XM_003626 } \\
900 / 19210\end{array}$ & $\begin{array}{l}\text { TGCTCAACTTGCC } \\
\text { AAAGCAC }\end{array}$ & $\begin{array}{l}\text { GGAATGAACCATC } \\
\text { CCAGCCA }\end{array}$ & 111 & 108.9 & 0.999 \\
\hline MsYSLI & $\begin{array}{l}\text { XM_024781 } \\
439 / 4892\end{array}$ & $\begin{array}{l}\text { CAAGAAGCAAGT } \\
\text { GCATGGGT }\end{array}$ & $\begin{array}{l}\text { TCCACAGTCTTCTT } \\
\text { TGCCTGAG }\end{array}$ & 94 & 111.0 & 0.999 \\
\hline MsMTP1 & $\begin{array}{l}\text { FJ389717/67 } \\
347\end{array}$ & $\begin{array}{l}\text { TGCAGCATTTGCC } \\
\text { ATCTCCT }\end{array}$ & $\begin{array}{l}\text { TGCATAGAAACCA } \\
\text { AAGCACCA }\end{array}$ & 114 & 104.5 & 0.999 \\
\hline$M s N A S 1$ & $\begin{array}{l}\text { XM_003594 } \\
705 / 61146\end{array}$ & $\begin{array}{l}\text { GCTAGCTTGGCTG } \\
\text { AAGATTGG }\end{array}$ & $\begin{array}{l}\text { AGATACAAAGCAC } \\
\text { TCGGAGACA }\end{array}$ & 87 & 100.5 & 0.999 \\
\hline $\begin{array}{l}M s A C T- \\
101\end{array}$ & $\begin{array}{l}\text { XM_003593 } \\
074 / 89028\end{array}$ & $\begin{array}{l}\text { TCTCTGTATGCCA } \\
\text { GTGGACG }\end{array}$ & $\begin{array}{l}\text { TCTGTTAAATCAC } \\
\text { GCCCAGCA }\end{array}$ & 140 & 102.4 & 0.999 \\
\hline MsEF1- $\square$ & $\begin{array}{l}\text { XM_003618 } \\
727 / 56897\end{array}$ & $\begin{array}{l}\text { CCACAGACAAGC } \\
\text { CCCTCAG }\end{array}$ & $\begin{array}{l}\text { TCACAACCATACC } \\
\text { GGGCTTC }\end{array}$ & 114 & 100.2 & 0.999 \\
\hline
\end{tabular}

"See Fig. 1 for the full names of the genes

${ }^{\dagger}$ NCBI - GenBank Accession number - https://www.ncbi.nlm.nih.gov/genbank/

* AGED - The Alfalfa Gene Index and Expression Atlas Database - http://plantgrn.noble.org/AGED/ 


\section{Figure legends}

615 Figure 1. Zinc ( $\mathrm{Zn})$ concentrations in shoots and roots of alfalfa (Medicago sativa) five days after the application of $\mathrm{Zn}$ doses of $0,0.01,0.1,0.5,1$ or $10 \mathrm{mg} \mathrm{Zn} \mathrm{plant}^{-1}$ to leaves. Means \pm standard error of three replicates are shown. Differences among the applied $\mathrm{Zn}$ doses were tested separately for shoot and root by one-way analysis of variance. Different letters denote significant differences in $\mathrm{Zn}$ concentrations in shoots and roots independently, according to Tukey-B honestly test $(P<$ $0.05)$.

Figure 2. Relative expression of seven transmembrane zinc $(\mathrm{Zn})$ transporter genes (MsZIP1-7) five days after the application of $\mathrm{Zn}$ doses of $0,0.1,1$ or10 $\mathrm{mg} \mathrm{Zn} \mathrm{plant}^{-1}$ to leaves of alfalfa (Medicago sativa). Means \pm standard error of three replicates are shown. The expression levels were calculated relative to reference genes ( $M s A C T-101$ for shoot and $M s E F 1-\alpha$ for root) and to the control (0 mg $\left.\mathrm{Zn}_{\text {plant }}{ }^{-1}\right)$. The broken line denotes the threshold between up- and down-regulation relative to the control. Differences in the expressions of each gene after different $\mathrm{Zn}$ doses were tested separately for shoot and root by one-way analysis of variance. Different letters denote significant differences among $\mathrm{Zn}$ doses, according to Tukey-B test $(P<0.05)$. The full names of the genes are reported in the legend of Figure 1.

Figure 3. Relative expression of genes related to $\mathrm{Zn}$ transport processes (MsZIF1, MsHMA4, MsYSL1, MsMTP1 and MsNAS1) five days after the application of $\mathrm{Zn}$ doses of 0, 0.1, 1 and $10 \mathrm{mg}$ $\mathrm{Zn}$ plant $^{-1}$ to leaves of alfalfa (Medicago sativa). Means \pm standard error of three replicates are shown. The expression levels were calculated relative to reference genes (MsACT-101 for shoot and MsEF1- $\alpha$ for root) and to the control (0 mg Zn plant $\left.{ }^{-1}\right)$. The broken line denotes the threshold between up- and down-regulation relative to the control. Differences in the expression of each gene at the different $\mathrm{Zn}$ doses were tested separately for shoot and root by one-way analysis of variance. 
639 Different letters denote significant differences among $\mathrm{Zn}$ doses, according to Tukey-B test $(P<$ 640 0.05). The full names of the genes are reported in the legend of Figure 1.

642 Figure 4. Heatmaps reporting the correlations between the differences in expression of genes related to zinc $(\mathrm{Zn})$ transport processes in alfalfa (Medicago sativa) after foliar application of $\mathrm{Zn}$ doses of $0.1,1$ and $10 \mathrm{mg} \mathrm{Zn} \mathrm{plant}^{-1}$ relative to a control dose of $0 \mathrm{mg} \mathrm{Zn} \mathrm{plant}^{-1}$. The similarity in the degree of correlation in fold-change of gene expression to $\mathrm{Zn}$ application relative to the control is based on the average linkage clustering of the Pearson correlations (r). In the clustering trees the genes are indicated in brown for roots and in green for shoots, while the ranks of correlations of the heatmap are indicated by color intensity (r 0 to 1 : from low to strong intensity of green). Seven genes encoding transmembrane $\mathrm{Zn}$ transporter $\left(M s Z I P_{1-7}\right)(\mathrm{a})$; four genes encoding cellular $\mathrm{Zn}$ transporters (including vacuolar transporters) (MsZIF1, MsHMA4, MsYSL1 and MsMTP1) and a gene encoding a nicotianamine synthase $(M s N A S 1)(\mathrm{b})$.

Figure 5. Suggested model for the roles of putative genes encoding proteins involved in $\mathrm{Zinc}(\mathrm{Zn})$ transport-related processes in alfalfa (Medicago sativa). The sites of action in the plant (i.e., root cytoplasm, rc; root vacuole, rv; xylem and apoplast, X/A; phoelm, P; leaf cytoplasm, lc; leaf vacuole, lv) and the element (E) fluxes $\left(\mathrm{K}_{1-13}\right)$ are reported. The concentration of the element is indicated in each site $[\mathrm{E}]$. The scheme synthetizes information across studies in various plants. Gene abbreviations: ZIP, Zrt-/Irt-like Protein; NAS, Nicotianamine synthase; ZIF, Zinc-Induced Facilitator; MTP, Metal Transporter Protein; HMA, $\mathrm{P}_{1 \mathrm{~B}}$-type Heavy Metal ATPase; YSL, Yellow 660 Stripe Like Protein; ZIP? indicates a generic ZIP; free diffusion: diffusion through leaf epidermis; 661 stomata: absorption through stomata. Plant abbreviations: Mt, Medicago truncatula; At,

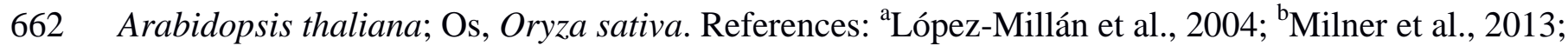
$663{ }^{\mathrm{c}}$ Aarts, 2014; ${ }^{\mathrm{d}}$ Clemens et al., 2013; ${ }^{\mathrm{e}}$ Curie et al., 2009; ${ }^{\mathrm{f}}$ Haydon et al., 2012; ${ }^{\mathrm{g}}$ Desbrosses-Fonrouge 
2015; ${ }^{1}$ Fageria et al., 2009.

\section{LITERATURE CITED}

Aarts MG (2014) Nicotianamine secretion for zinc excess tolerance. Plant Physiol 166: 751-752.

Albert IL, Nadassy K, Wodak SJ (1998) Analysis of zinc binding sites in protein crystal structures. Protein Sci 7: 1700-1716

Alloway BJ (2008) Zinc in soils and crop nutrition. $2^{\text {nd }}$ ed. IZA and IFA, Brussels, Belgium and Paris, France

Alloway BJ (2009) Soil factors associated with zinc deficiency in crops and humans. Environ Geochem Hlth 31: 537-548

Anderson MJ (2001) A new method for non-parametric multivariate analysis of variance. Austral Ecol 26: $32-46$

Anderson M, Braak CT (2003) Permutation tests for multi-factorial analysis of variance. J Stat Comput Sim 73: 85-113

Anderson MJ, Ellingsen KE, McArdle BH (2006) Multivariate dispersion as a measure of beta diversity. Ecol Lett 9: 683-693

Andrés-Colás N, Sancenón V, Rodríguez-Navarro S, Mayo S, Thiele DJ, Ecker JR, Puig S, Peñarrubia L (2006) The Arabidopsis heavy metal P-type ATPase HMA5 interacts with metallochaperones and functions in copper detoxification of roots. Plant J 45: 225-236

Baker AJ, Whiting SN (2002) In search of the Holy Grail - a further step in understanding metal hyperaccumulation? New Phytol 155: 1-4

Becher M, Talke IN, Krall L, Krämer U (2004) Cross-species microarray transcript profiling reveals high constitutive expression of metal homeostasis genes in shoots of the zinc hyperaccumulator Arabidopsis halleri. Plant J 37: 251-268

Broadley MR, Brown P, Cakmak I, Rengel Z, Zhao F (2012) Function of nutrients: micronutrients. In: Marschner P, ed. Marschner's mineral nutrition of higher plant $3^{\text {rd }}$ edn. 
Academic Press, pp 191-248

Broadley MR, White PJ, Hammond JP, Zelko I, Lux A (2007) Zinc in plants. New Phytol 173: $677-702$

Bughio N, Yamaguchi H, Nishizawa NK, Nakanishi H, Mori S (2002) Cloning an iron-regulated metal transporter from rice. J Exp Bot 53: 1677-1682

Burleigh SH, Kristensen BK, Bechmann IE (2003) A plasma membrane zinc transporter from Medicago truncatula is up-regulated in roots by $\mathrm{Zn}$ fertilization, yet down-regulated by arbuscular mycorrhizal colonization. Plant Mol Biol 52: 1077-1088

Cakmak I (2008) Enrichment of cereal grains with zinc: agronomic or genetic biofortification? Plant Soil 302: 1-17

Cakmak I (2012) HarvestPlus zinc fertilizer project: HarvestZinc. Better Crops 96: 17-19

Cakmak I, Pfeiffer WH, McClafferty B (2010) Biofortification of durum wheat with zinc and iron. Cereal Chem 87: 10-20

Cakmak I, McLaughlin MJ, White P (2017) Zinc for better crop production and human health. Plant Soil 411: 1-4

Caldelas C, Weiss DJ (2017) Zinc homeostasis and isotopic fractionation in plants: a review. Plant Soil 411: 17-46

Capstaff NM, Miller AJ (2018) Improving the yield and nutritional quality of forage crops. Front Plant Sci 9: 1-18

\section{Cakmak I, Torun A, Millet E, Feldman M, Fahima T, Korol A, Nevo E, Braun HJ, Özkan H} (2004) Triticum dicoccoides: an important genetic resource for increasing zinc and iron concentration in modern cultivated wheat. Soil Sci Plant Nutr 50:1047-1054 
Ciccolini V, Pellegrino E, Coccina A, Fiaschi AI, Cerretani D, Sgherri C, Quartacci MF, Ercoli L (2017) Biofortification with iron and zinc improves nutritional and nutraceutical properties of common wheat flour and bread. J Agr Food Chem 65: 5443-5452

Clarke KR, Gorley RN (2015) Getting started with PRIMER v7. Plymouth Marine Laboratory, Plymouth, UK: PRIMER-E, 20

Clemens S, Deinlein U, Ahmadi H, Höreth S, Uraguchi S (2013) Nicotianamine is a major player in plant $\mathrm{Zn}$ homeostasis. Biometals 26: 623-632

Curie C, Cassin G, Couch D, Divol F, Higuchi K, Le Jean M, Misson J, Shikora A, Czernic P, Mari S (2009) Metal movement within the plant: contribution of nicotianamine and yellow stripe 1-like transporters. Ann Bot-London 103: 1-11

Deinlein U, Weber M, Schmidt H, Rensch S, Trampczynska A, Hansen TH, Husted S, Schjoerring, JK, Talke IN, Krämer U, et al. (2012) Elevated nicotianamine levels in Arabidopsis halleri roots play a key role in zinc hyperaccumulation. Plant Cell 24: 708-723

Desbrosses-Fonrouge AG, Voigt K, Schröder A, Arrivault S, Thomine S, Krämer U (2005) Arabidopsis thaliana MTP1 is a $\mathrm{Zn}$ transporter in the vacuolar membrane which mediates $\mathrm{Zn}$ detoxification and drives leaf $\mathrm{Zn}$ accumulation. FEBS Lett 579: 4165-4174

Deshpande P, Dapkekar A, Oak MD, Paknikar KM, Rajwade JM (2017) Zinc complexed chitosan/TPP nanoparticles: a promising micronutrient nanocarrier suited for foliar application. Carbohyd Polym 165: 394-401

Desjardins P, Conklin D (2010) NanoDrop microvolume quantitation of nucleic acids. JOVE-J Vis Exp 5: e2565

Di Baccio D, Tognetti R, Minnocci A, Sebastiani L (2009) Responses of the Populus x euramericana clone I-214 to excess zinc: carbon assimilation, structural modifications, metal distribution and cellular localization. Environ Exp Bot 67: 153-163

Eckhardt U, Marques AM, Buckhout TJ (2001) Two iron-regulated cation transporters from tomato complement metal uptake-deficient yeast mutants. Plant Mol Biol 45: 437-448 
Eide D, Broderius M, Fett, J Guerinot ML (1996) A novel iron-regulated metal transporter from plants identified by functional expression in yeast. P Natl Acad Sci USA 93: 5624-5628

Erenoglu EB, Kutman UB, Ceylan Y, Yildiz B, Cakmak I (2011) Improved nitrogen nutrition enhances root uptake, root-to-shoot translocation and remobilization of zinc $\left({ }^{65} \mathrm{Zn}\right)$ in wheat. New Phytol 189: 438-448

Fageria NK, Filho MB, Moreira A, Guimarães CM (2009) Foliar fertilization of crop plants. J Plant Nutr 32: 1044-1064

Foroughi S, Baker AJM, Roessner U, Johnson AAT, Bacic A, Callahan DL (2014) Hyperaccumulation of zinc by Noccaea caerulescens results in a cascade of stress responses and changes in the elemental profile. Metallomics 6: 1671-1682

Foyer CH, Lam H-M, Nguyen HT, Siddique KHM, Varshney RK, Colmer TD, Cowling W,

Bramley H, Mori TA, Hodgson JM, et al (2016) Neglecting legumes has compromised human health and sustainable food production. Nat Plants 2: 16112

Geissler C, Powers HJ (2017) Human nutrition. Oxford University Press, Oxford, UK

Gregory PJ, Wahbi A, Adu-Gyamfi J, Heiling M, Gruber R, Joy EJM, Broadley MR (2017) Approaches to reduce zinc and iron deficits in food systems. Global Food Secur-Agr 15: 1-10

Grotz N, Fox T, Connolly E, Park W, Guerinot ML, Eide D (1998) Identification of a family of zinc transporter genes from Arabidopsis that respond to zinc deficiency. P Natl Acad Sci USA 95: $7220-7224$

Grotz N, Guerinot ML (2006) Molecular aspects of $\mathrm{Cu}$, Fe and $\mathrm{Zn}$ homeostasis in plants. Biochim Biophys Acta 1763: 595-608

Gustin JL, Loureiro ME, Kim D, Na G, Tikhonova M, Salt DE (2009) MTP1-dependent Zn sequestration into shoot vacuoles suggests dual roles in $\mathrm{Zn}$ tolerance and accumulation in $\mathrm{Zn}$ hyperaccumulating plants. Plant J 57: 1116-1127 
Hanikenne M, Talke IN, Haydon MJ, Lanz C, Nolte A, Motte P, Kroymann J, Weigel D, Krämer U (2008) Evolution of metal hyperaccumulation required cis-regulatory changes and triplication of HMA4. Nature 453: 391-395

Haydon MJ, Cobbett CS (2007) A novel major facilitator superfamily protein at the tonoplast influences zinc tolerance and accumulation in Arabidopsis. Plant Physiol 143: 1705-1719

Haydon MJ, Kawachi M, Wirtz M, Hillmer S, Hell R, Krämer U (2012) Vacuolar nicotianamine has critical and distinct roles under iron deficiency and for zinc sequestration in Arabidopsis. Plant Cell 24: 724

Hermand V, Julio E, de Borne FD, Punshon T, Ricachenevsky FK, Bellec A, Gosti F, Berthomieu P (2014) Inactivation of two newly identified tobacco heavy metal ATPases leads to reduced $\mathrm{Zn}$ and $\mathrm{Cd}$ accumulation in shoots and reduced pollen germination. Metallomics 6: 1427-1440

Ishimaru Y, Suzuki M, Tsukamoto T, Suzuki K, Nakazono M, Kobayashi T, Wada Y, Watanabe S., Matsuhashi S, Nakanishi H, et al (2006) Rice plants take up iron as an Fe3pphytosiderophore and as Fe2p. Plant J 45: 335-346

Hussain D, Haydon MJ, Wang Y, Wong E, Sherson SM, Young J, Camakaris J, Harper JF, Cobbett CS (2004) P-type ATPase heavy metal transporters with roles in essential zinc homeostasis in Arabidopsis. Plant Cell 16: 1327-1339 
Kolaj-Robin O, Russell D, Hayes KA, Pembroke JT, Soulimane T (2015) Cation diffusion facilitator family: structure and function. FEBS Lett 589: 1283-1295

Kumar S, Stecher G, Li M, Knyaz C, Tamura K (2018) MEGA X: molecular evolutionary genetics analysis across computing platforms. Mol Biol Evol 35: 1547-1549

Kumssa DB, Joy EJ, Ander EL, Watts MJ, Young SD, Walker S, Broadley MR (2015) Dietary calcium and zinc deficiency risks are decreasing but remain prevalent. Sci Rep 5: 10974

Li S, Zhou X, Huang Y, Zhu L, Zhang S, Zhao Y, Chen R (2013) Identification and characterization of the zinc-regulated transporters, iron-regulated transporter-like protein (ZIP) gene family in maize. BMC Plant Biol 13: 114

Livak K J, Schmittgen, TD (2001) Analysis of relative gene expression data using real-time quantitative PCR and the $2-\Delta \Delta C T$ method. Methods 25: 402-408

López-Millán AF, Ellis DR, Grusak MA (2004) Identification and characterization of several new members of the ZIP family of metal ion transporters in Medicago truncatula. Plant Mol Biol 54: $583-596$

Mäser P, Thomine S, Schroeder JI, Ward JM, Hirsch K, Sze H, Talke IN, Amtmann A, Maathuis FJM, Sanders D, et al. (2001) Phylogenetic relationship within cation transporter families of Arabidopsis. Plant Physiol 126: 1646-1667

McDonald P, Edwards RA, Greenhalgh JFD, Morgan CA (2002) Animal nutrition. Switzerland: Pearson Education Limited, Harlow, UK

Milner MJ, Seamon J, Craft E, Kochian LV (2013) Transport properties of members of the ZIP family in plants and their role in Zn and Mn homeostasis. J Exp Bot 64: 369-381

Nei M, Kumar S (2000) Molecular evolution and phylogenetics. Oxford University Press, Oxford, UK

Nicot N, Hausman JF, Hoffmann L, Evers D (2005) Housekeeping gene selection for real-time RT-PCR normalization in potato during biotic and abiotic stress. J Exp Bot 56: 2907-2914 
815 Nölte J (2003) ICP Emission Spectrometry: a practical guide (Vol. 1). Wiley-VCH Weinheim, Germany

Ó Lochlainn S, Bowen HC, Fray RG, Hammond JP, King GJ, White PJ, Broadley MR (2011)

Olsen LI, Palmgren MG (2014) Many rivers to cross: the journey of zinc from soil to seed. Front Plant Sci 5: 30

O'Rourke JA, Fu F, Bucciarelli B, Yang SS, Samac DA, Lamb JF, Li J, Dai X, Zhao PX, Vance CP (2015) The Medicago sativa gene index 1.2: a web-accessible gene expression atlas for investigating expression differences between Medicago sativa subspecies. BMC Genomics 16: 502 Nat Chem Biol 5: 333-340

Pedas P, Ytting CK, Fuglsang AT, Jahn TP, Schjoerring JK, Husted S (2008) Manganese efficiency in barley: identification and characterization of the metal ion transporter HvIRT1.

Prasad AS (2013) Discovery of human zinc deficiency: its impact on human health and disease. Adv Nutr 4: 176-190 Plant Physiol 148: 455-466

Pita-Barbosa A, Ricachenevsky FK, Wilson M, Dottorini T, Salt DE (2019) Transcriptional plasticity buffers genetic variation in zinc homeostasis. Sci Rep 9: 1-11

Ramesh SA, Shin R, Eide DJ, Schachtman DP (2003) Differential metal selectivity and gene expression of two zinc transporters from rice. Plant Physiol 133: 126-134

Rawat N, Neelam K, Tiwari VK, Dhaliwal HS (2013) Biofortification of cereals to overcome hidden hunger. Plant Breeding 132: 437-445

Saitou N, Nei M (1987) The neighbor-joining method: a new method for reconstructing phylogenetic trees. Mol Biol Evol 4: 406-425 
Saltzman A, Birol E, Bouis HE, Boy E, De Moura FF, Islam Y, Pfeiffer WH (2013) Biofortification: progress toward a more nourishing future. Glob Food Secur-Agr 2: 9-17

Sankaran RP, Huguet T, Grusak MA (2009) Identification of QTL affecting seed mineral concentrations and content in the model legume Medicago truncatula. Theor Appl Genet 119: 241-253

Sasaki H, Hirose T, Watanabe Y, Ohsugi R (1998) Carbonic anhydrase activity and $\mathrm{CO}_{2}$-transfer resistance in Zn-deficient rice leaves. Plant Physiol 118: 929-934

Sasaki A, Yamaji N, Mitani-Ueno N, Kashino M, Ma JF (2015) A node-localized transporter OsZIP3 is responsible for the preferential distribution of $\mathrm{Zn}$ to developing tissues in rice. Plant J 84: 374-384

Sharma SS, Dietz KJ, Mimura T (2016) Vacuolar compartmentalization as indispensable component of heavy metal detoxification in plants. Plant Cell Environ 39: 1112-1126

Sinclair SA, Senger T, Talke IN, Cobbett CS, Haydon MJ, Kraemer U (2018) Systemic

Talke IN, Hanikenne M, Krämer U (2006) Zinc-dependent global transcriptional control, transcriptional deregulation, and higher gene copy number for genes in metal homeostasis of the hyperaccumulator Arabidopsis halleri. Plant Physiol 142: 148-167

Tiong J, McDonald G, Genc Y, Shirley N, Langridge P, Huang CY (2015) Increased expression 
Weber M, Harada E, Vess C, Roepenack-Lahaye EV, Clemens S (2004) Comparative microarray analysis of Arabidopsis thaliana and Arabidopsis halleri roots identifies nicotianamine synthase, a ZIP transporter and other genes as potential metal hyperaccumulation factors. Plant J 37: 269-281

White PJ (2012) Long-distance transport in the xylem and phloem. In Marschner P, ed. Marschner's mineral nutrition of higher plants. $3^{\text {rd }}$ edn. Academic Press, pp 49-70

White PJ (2016) Biofortification of Edible Crops. eLS 1-8

White PJ, Broadley MR (2005) Biofortifying crops with essential mineral elements. Trends Plant Sci 10: 586-593

White PJ, Broadley MR (2009) Biofortification of crops with seven mineral elements often lacking in human diets-iron, zinc, copper, calcium, magnesium, selenium and iodine. New Phytol 182: 49-84

White PJ, Broadley MR (2011) Physiological limits to zinc biofortification of edible crops. Front Plant Sci 2: 80

White PJ, Pongrac P (2017) Heavy-metal toxicity in plants. In: Shabala S, ed. Plant Stress Physiology, $2^{\text {nd }}$ ed., Wallingford, UK, pp 301-331.

White PJ, Thompson JA, Wright G, Rasmussen SK (2017) Biofortifying Scottish potatoes with zinc. Plant Soil 411: 151-165

WHO (2005) Comparative quantification of health risks: global and regional burden of diseases attributable to selected major risk factors. In: Ezzati M, Lopez AD, Rodgers A., Murray CJL. eds. World Health Organization, Geneva, Switzerland.

Wickham H (2011) ggplot2. Wires Comput Stat 3: 180-185 profiles of Arabidopsis thaliana in mineral deficiencies reveal novel transporters involved in metal homeostasis. J Biol Chem 278: 47644-47653 
with root uptake and grain translocation of zinc in wild emmer and durum wheat genotypes. Plant Soil 411: 69-79

895 Zhao H, Eide D (1996) The yeast ZRT1 gene encodes the zinc transporter protein of a high-affinity uptake system induced by zinc limitation. P Natl Acad Sci USA 93: 2454-2458 


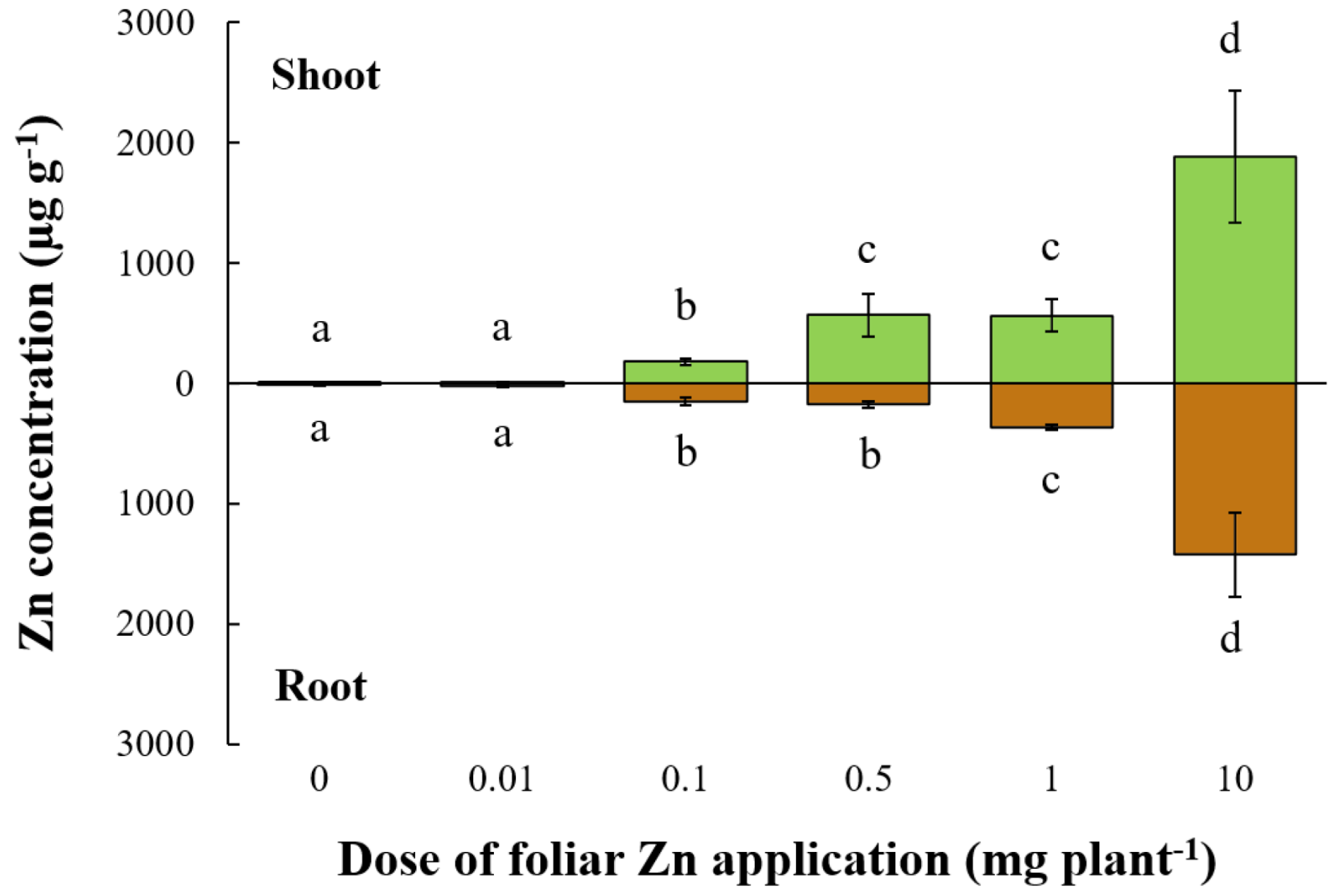

Figure 1. Zinc ( $\mathrm{Zn}$ ) concentrations in shoots and roots of alfalfa (Medicago sativa) five days after the application of $\mathrm{Zn}$ doses of $0,0.01,0.1,0.5,1$ or $10 \mathrm{mg} \mathrm{Zn} \mathrm{plant}^{-1}$ to leaves. Means \pm standard error of three replicates are shown. Differences among the applied $\mathrm{Zn}$ doses were tested separately for shoot and root by one-way analysis of variance. Different letters denote significant differences in $\mathrm{Zn}$ concentrations in shoots and roots independently, according to Tukey-B honestly test $(P<0.05)$. 


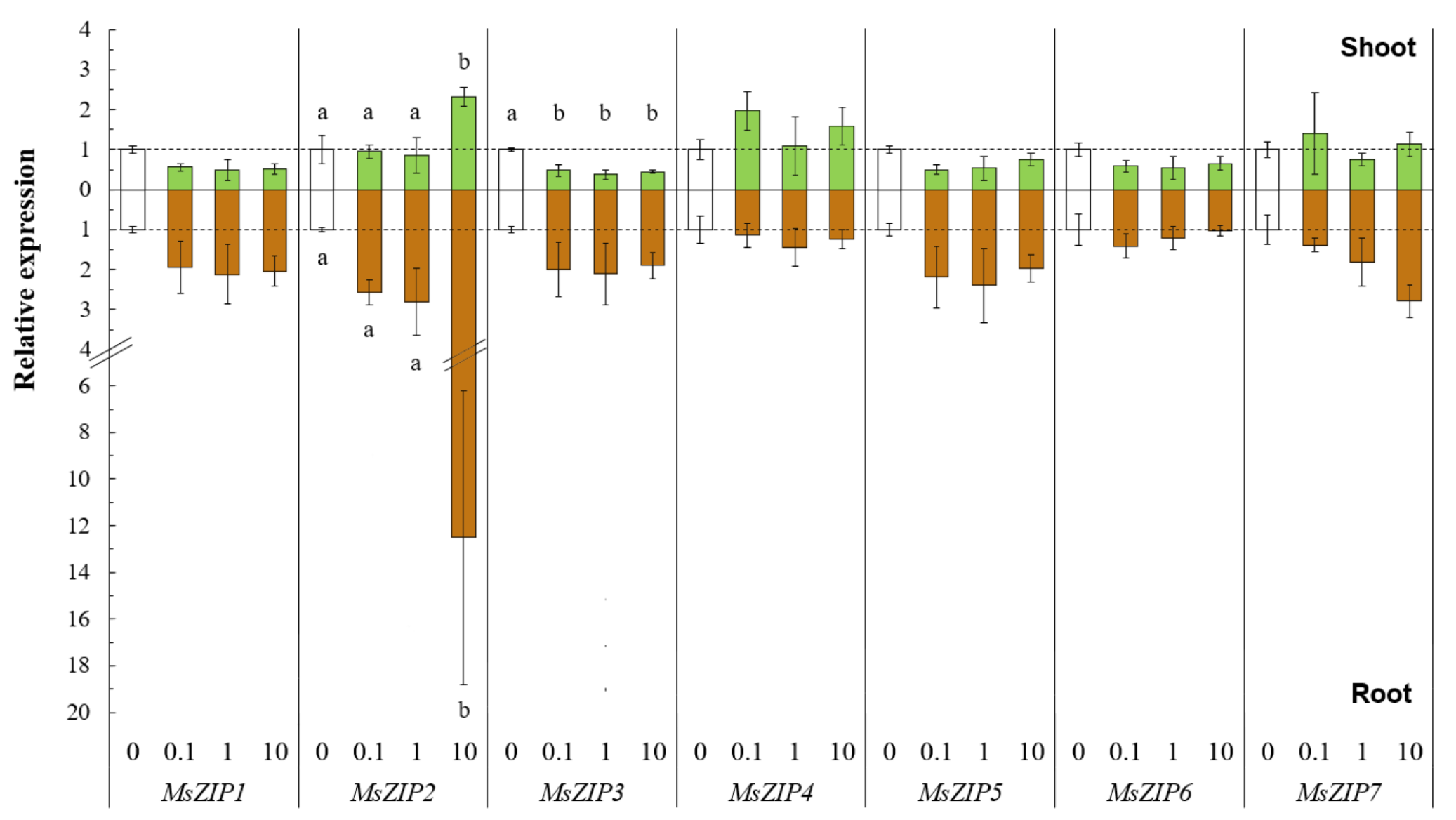

Dose of foliar Zn application (mg plant ${ }^{-1}$ )

Figure 2. Relative expression of seven transmembrane zinc ( $\mathrm{Zn})$ transporter genes (MsZIP1-7) five days after the application of $\mathrm{Zn}$ doses of 0, 0.1, 1 or $10 \mathrm{mg} \mathrm{Zn} \mathrm{plant}^{-1}$ to leaves of alfalfa (Medicago sativa). Means \pm standard error of three replicates are shown. The expression levels were calculated relative to reference genes (MsACT-101 for shoot and $M s E F 1-\alpha$ for root) and to the control $\left(0 \mathrm{mg} \mathrm{Zn} \mathrm{plant}^{-1}\right)$. The broken line denotes the threshold between up- and downregulation relative to the control. Differences in the expressions of each gene after different $\mathrm{Zn}$ doses were tested separately for shoot and root by one-way analysis of variance. Different letters denote significant differences among $\mathrm{Zn}$ doses, according to Tukey-B test $(P<0.05)$. 


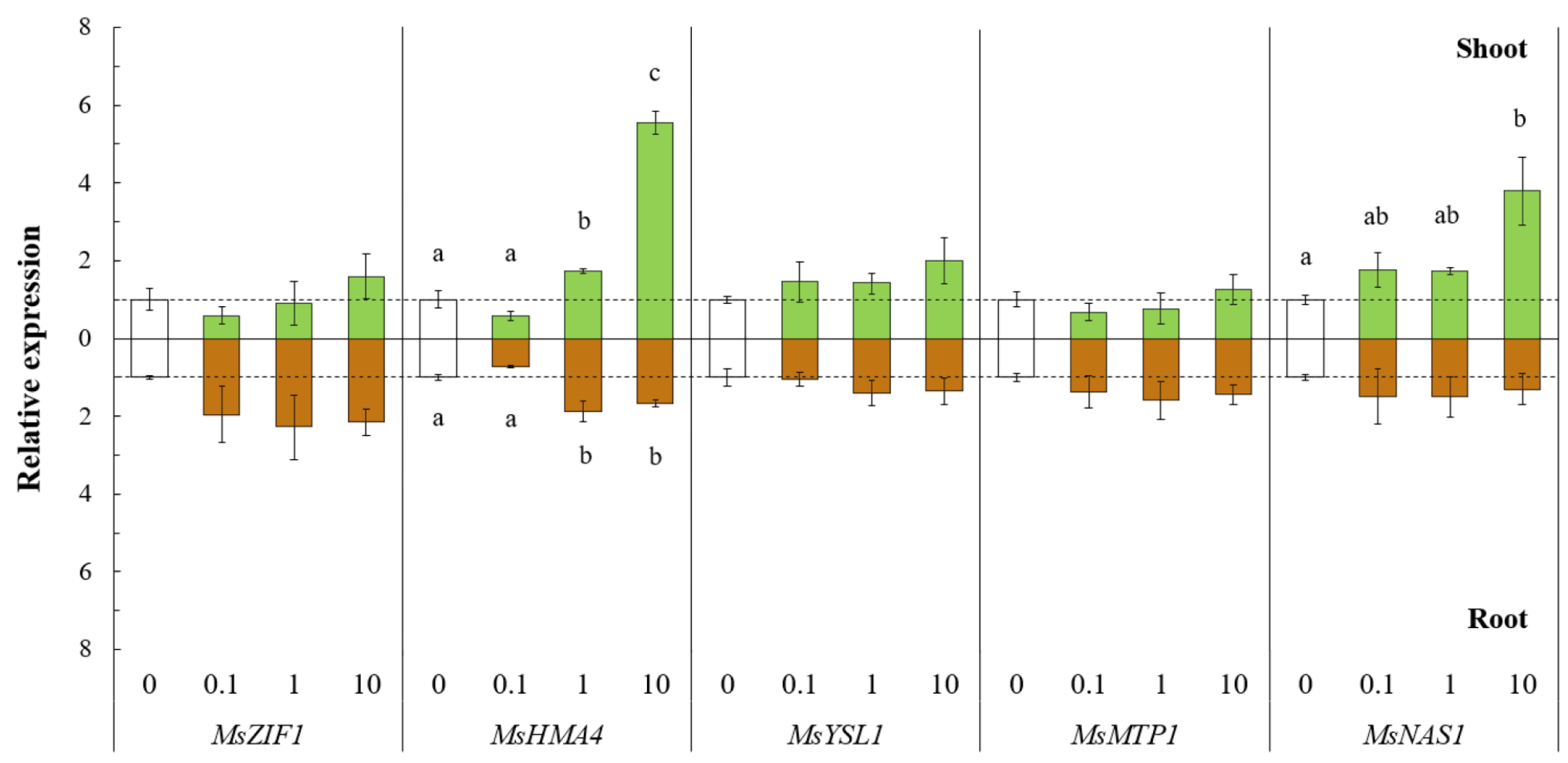

\section{Dose of foliar $\mathrm{Zn}$ application (mg plant ${ }^{-1}$ )}

Figure 3. Relative expression of genes related to $\mathrm{Zn}$ transport processes (MsZIF1, MsHMA4, MsYSL1, MsMTP1 and $M s N A S 1$ ) five days after the application of $\mathrm{Zn}$ doses of $0,0.1,1$ or $10 \mathrm{mg} \mathrm{Zn} \mathrm{plant}^{-1}$ to leaves of alfalfa (Medicago sativa). Means \pm standard error of three replicates are shown. The expression levels were calculated relative to reference genes (MsACT-101 for shoot and MsEF1- $\alpha$ for root) and to the control ( $0 \mathrm{mg} \mathrm{Zn} \mathrm{plant}^{-1}$ ). The broken line denotes the threshold between up- and down-regulation relative to the control. Differences in the expression of each gene at the different $\mathrm{Zn}$ doses were tested separately for shoot and root by one-way analysis of variance. Different letters denote significant differences among $\mathrm{Zn}$ doses, according to Tukey-B test $(P<0.05)$. 
a)

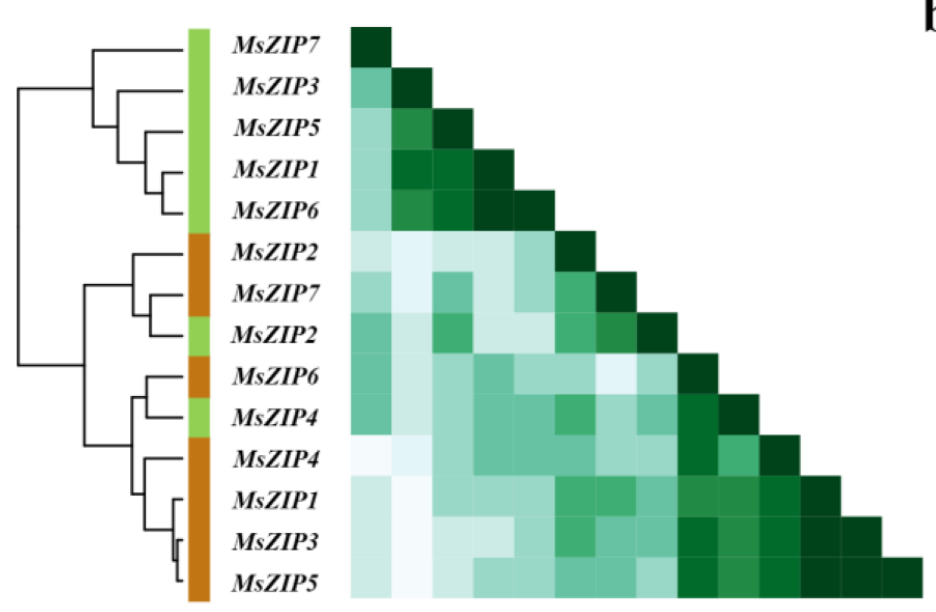

Shoot

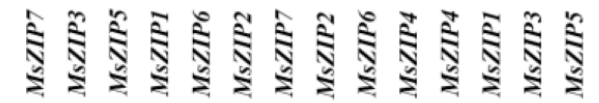

Root b)

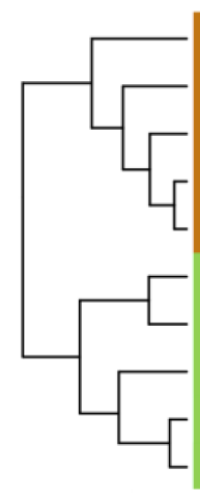

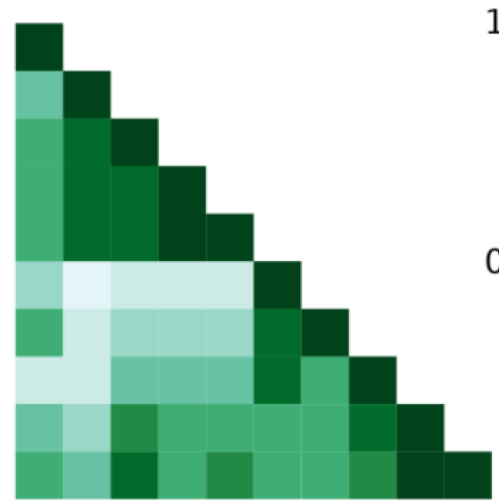

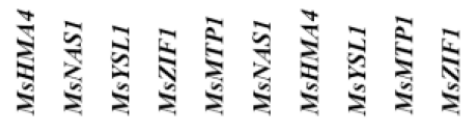

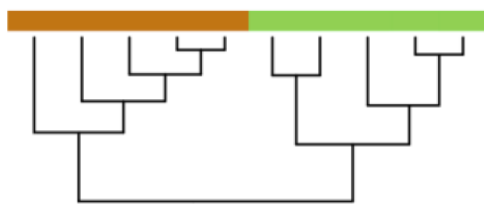

Figure 4. Heatmaps reporting the correlations between the differences in expression of genes related to zinc ( $\mathrm{Zn}$ ) transport processes in alfalfa (Medicago sativa) after foliar application of $\mathrm{Zn}$ doses of $0.1,1$ or $10 \mathrm{mg} \mathrm{Zn} \mathrm{plant}^{-1}$ relative to a control dose of $0 \mathrm{mg} \mathrm{Zn}$ plant ${ }^{-1}$. The similarity in the degree of correlation in fold-change of gene expression to $\mathrm{Zn}$ application relative to the control is based on the average linkage clustering of the Pearson correlations (r). In the clustering trees the genes are indicated in brown for roots and in green for shoots, while the ranks of correlations of the heatmap are indicated by color intensity ( $\mathrm{r} 0$ to 1 : from low to strong intensity of green). Seven genes encoding transmembrane $\mathrm{Zn}$ transporter $\left(M s Z I P_{1-7}\right)$ (a); four genes encoding cellular $\mathrm{Zn}$ transporters (including vacuolar transporters) (MsZIF1, MsHMA4, MsYSL1 and MsMTP1) and a gene encoding a nicotianamine synthase (MsNASl) (b). 


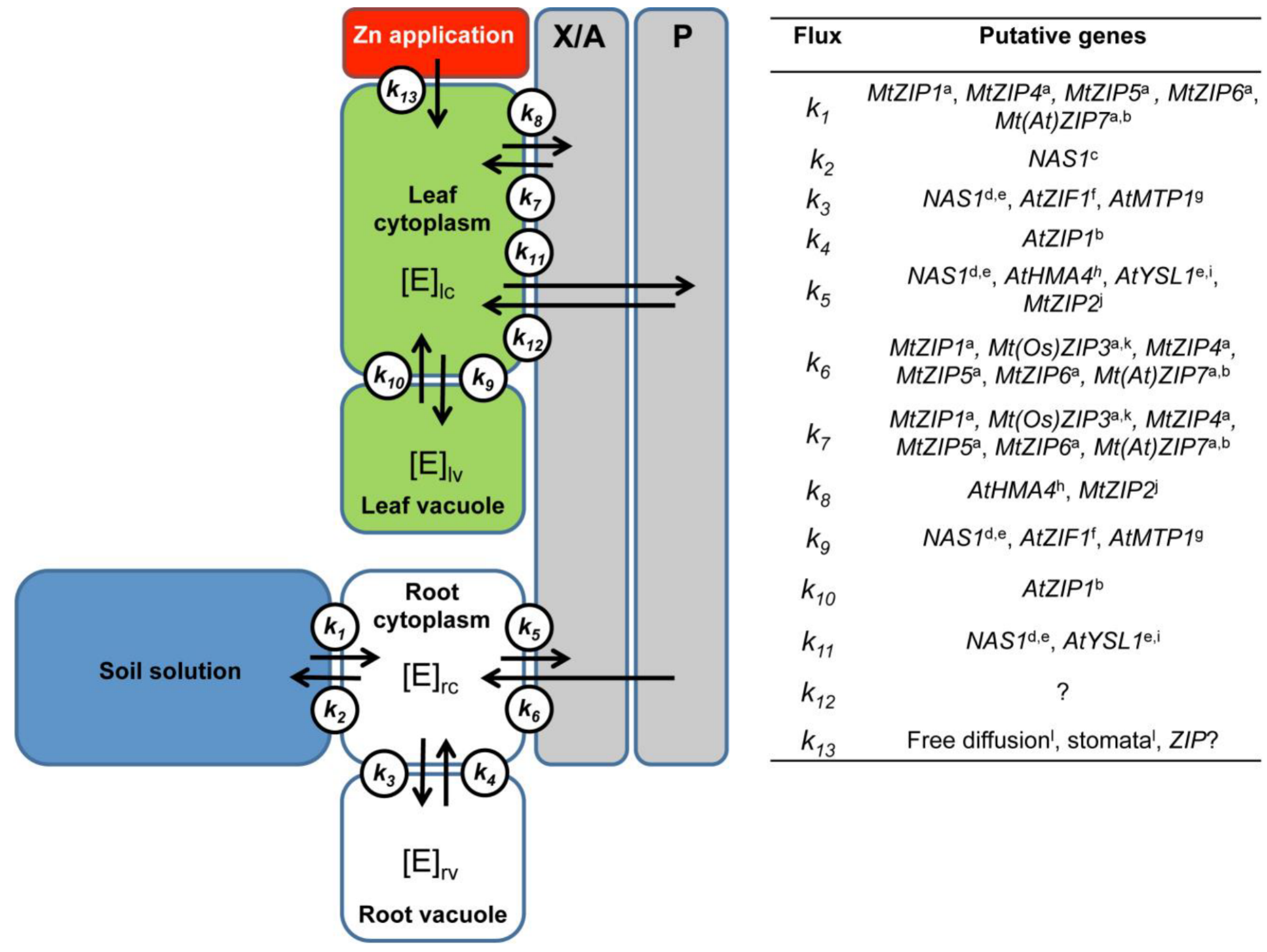

Figure 5. Suggested model for the roles of putative genes encoding proteins involved in Zinc (Zn) transport-related processes in alfalfa (Medicago sativa). The sites of action in the plant (i.e., root cytoplasm, rc; root vacuole, rv; xylem and apoplast, X/A; phoelm, P; leaf cytoplasm, lc; leaf vacuole, lv) and the element (E) fluxes $\left(\mathrm{K}_{1-13}\right)$ are reported The concentration of the element is indicated in each site $[\mathrm{E}]$. The scheme synthetizes information across studies in various plants. Gene abbreviations: ZIP, Zrt-/Irt-like Protein; NAS, Nicotianamine synthase; ZIF, Zinc-Induced Facilitator; MTP, Metal Transporter Protein; HMA, $\mathrm{P}_{1 \mathrm{~B}}$-type Heavy Metal ATPase; YSL, Yellow Stripe Like Protein; ZIP? indicates a generic ZIP; free diffusion: diffusion through leaf epidermis; stomata: absorption through stomata. Plant abbreviations:

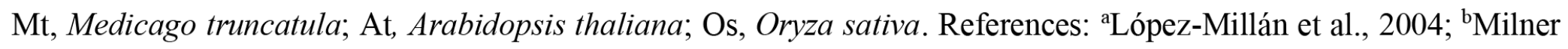

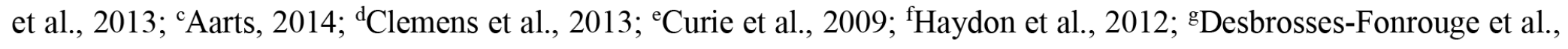

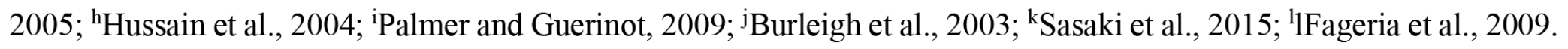




\section{Parsed Citations}

Aarts MG (2014) Nicotianamine secretion for zinc excess tolerance. Plant Physiol 166: 751-752.

Pubmed: Author and Title

Google Scholar: Author Only Title Only Author and Title

Albert IL, Nadassy K, Wodak SJ (1998) Analysis of zinc binding sites in protein crystal structures. Protein Sci 7: 1700-1716

Pubmed: Author and Title

Google Scholar: Author Only Title Only Author and Title

Alloway BJ (2008) Znc in soils and crop nutrition. 2nd ed. IZAand IFA, Brussels, Belgium and Paris, France

Pubmed: Author and Title

Google Scholar: Author Only Title Only Author and Title

Aloway BJ (2009) Soil factors associated with zinc deficiency in crops and humans. Environ Geochem Hlth 31: 537-548

Pubmed: Author and Title

Google Scholar: Author Only Title Only Author and Title

Anderson MJ (2001) Anew method for non-parametric multivariate analysis of variance. Austral Ecol 26: $32-46$

Pubmed: Author and Title

Google Scholar: Author Only Title Only Author and Title

Anderson M, Braak CT (2003) Permutation tests for multi-factorial analysis of variance. J Stat Comput Sim 73: 85-113

Pubmed: Author and Title

Google Scholar: Author Only Title Only Author and Title

Anderson MJ, Ellingsen KE, McArdle BH (2006) Multivariate dispersion as a measure of beta diversity. Ecol Lett 9: 683-693

Pubmed: Author and Title

Google Scholar: Author Only Title Only Author and Title

Andrés-Colás N, Sancenón V, Rodríguez-Navarro S, Mayo S, Thiele DJ, Ecker JR, Puig S, Peñarrubia L (2006) The Arabidopsis heavy metal P-type ATPase HMA5 interacts with metallochaperones and functions in copper detoxification of roots. Plant J 45: 225-236

Pubmed: Author and Title

Google Scholar: Author Only Title Only Author and Title

Baker AJ, Whiting SN (2002) In search of the Holy Grail - a further step in understanding metal hyperaccumulation? New Phytol 155: 1-4 Pubmed: Author and Title Google Scholar: Author Only Title Only Author and Title

Becher M, Talke IN, Krall L, Krämer U (2004) Cross-species microarray transcript profiling reveals high constitutive expression of metal homeostasis genes in shoots of the zinc hyperaccumulator Arabidopsis halleri. Plant J 37: 251-268

Pubmed: Author and Title

Google Scholar: Author Only Title Only Author and Title

Broadley MR, Brown P, Cakmak I, Rengel Z, Zhao F (2012) Function of nutrients: micronutrients. In: Marschner P, ed. Marschner's mineral nutrition of higher plant 3rd edn. Academic Press, pp 191-248

Pubmed: Author and Title

Google Scholar: Author Only Title Only Author and Title

Broadley MR, White PJ, Hammond JP, Zelko I, Lux A(2007) Znc in plants. New Phytol 173: 677-702

Pubmed: Author and Title

Google Scholar: Author Only Title Only Author and Title

Bughio N, Yamaguchi H, Nishizawa NK, Nakanishi H, Mori S (2002) Cloning an iron-regulated metal transporter from rice. J Exp Bot 53: 1677-1682

Pubmed: Author and Title

Google Scholar: Author Only Title Only Author and Title

Burleigh SH, Kristensen BK, Bechmann IE (2003) A plasma membrane zinc transporter from Medicago truncatula is up-regulated in roots by Zn fertilization, yet down-regulated by arbuscular mycorrhizal colonization. Plant Mol Biol 52: 1077-1088

Pubmed: Author and Title

Google Scholar: Author Only Title Only Author and Title

Cakmak I (2008) Enrichment of cereal grains with zinc: agronomic or genetic biofortification? Plant Soil 302: 1-17

Pubmed: Author and Title

Google Scholar: Author Only Title Only Author and Title

Cakmak I (2012) HarvestPlus zinc fertilizer project: HarvestZnc. Better Crops 96: 17-19

Pubmed: Author and Title

Google Scholar: Author Only Title Only Author and Title

Cakmak I, Pfeiffer WH, McClafferty B (2010) Biofortification of durum wheat with zinc and iron. Cereal Chem 87: 10-20

Pubmed: Author and Title

Google Scholar: Author Only Title Only Author and Title 
Cakmak I, McLaughlin MJ, White P (2017) Znc for better crop production and human health. Plant Soil 411: 1-4

Pubmed: Author and Title

Google Scholar: Author Only Title Only Author and Title

Cakmak I, Torun A, Millet E, Feldman M, Fahima T, Korol A, Nevo E, Braun HJ, Özkan H (2004) Triticum dicoccoides: an important genetic resource for increasing zinc and iron concentration in modern cultivated wheat. Soil Sci Plant Nutr 50:1047-1054

Pubmed: Author and Title

Google Scholar: Author Only Title Only Author and Title

Caldelas C, Weiss DJ (2017) Znc homeostasis and isotopic fractionation in plants: a review. Plant Soil 411: 17-46

Pubmed: Author and Title

Google Scholar: Author Only Title Only Author and Title

Capstaff NM, Miller AJ (2018) Improving the yield and nutritional quality of forage crops. Front Plant Sci 9: 1-18

Pubmed: Author and Title

Google Scholar: Author Only Title Only Author and Title

Chaney RL (1993) Znc phytotoxicity. In: Znc in soils and plants. Dordrecht, Netherlands: Springer, pp 135-150

Pubmed: Author and Title

Google Scholar: Author Only Title Only Author and Title

Ciccolini V, Pellegrino E, Coccina A, Fiaschi A, Cerretani D, Sgherri C, Quartacci MF, Ercoli L (2017) Biofortification with iron and zinc improves nutritional and nutraceutical properties of common wheat flour and bread. J Agr Food Chem 65: 5443-5452

Pubmed: Author and Title

Google Scholar: Author Only Title Only Author and Title

Clarke KR, Gorley RN (2015) Getting started with PRIMER v7. Plymouth Marine Laboratory, Plymouth, UK: PRIMER-E, 20

Pubmed: Author and Title

Google Scholar: Author Only Title Only Author and Title

Clemens S, Deinlein U, Ahmadi H, Höreth S, Uraguchi S (2013) Nicotianamine is a major player in plant Zn homeostasis. Biometals 26:

623-632

Pubmed: Author and Title

Google Scholar: Author Only Title Only Author and Title

Curie C, Cassin G, Couch D, Divol F, Higuchi K, Le Jean M, Misson J, Shikora A, Czernic P, Mari S (2009) Metal movement within the plant: contribution of nicotianamine and yellow stripe 1-like transporters. Ann Bot-London 103: 1-11

Pubmed: Author and Title

Google Scholar: Author Only Title Only Author and Title

Deinlein U, Weber M, Schmidt H, Rensch S, Trampczynska A, Hansen TH, Husted S, Schjoerring, JK, Talke IN, Krämer U, et al. (2012)

Elevated nicotianamine levels in Arabidopsis halleri roots play a key role in zinc hyperaccumulation. Plant Cell 24: 708-723

Pubmed: Author and Title

Google Scholar: Author Only Title Only Author and Title

Desbrosses-Fonrouge AG, Voigt K, Schröder A, Arrivault S, Thomine S, Krämer U (2005) Arabidopsis thaliana MTP1 is a Zn transporter in the vacuolar membrane which mediates Zn detoxification and drives leaf Zn accumulation. FEBS Lett 579: 4165-4174

Pubmed: Author and Title

Google Scholar: Author Only Title Only Author and Title

Deshpande P, Dapkekar A, Oak MD, Paknikar KM, Rajwade JM (2017) Znc complexed chitosan/TPP nanoparticles: a promising micronutrient nanocarrier suited for foliar application. Carbohyd Polym 165: 394-401

Pubmed: Author and Title

Google Scholar: Author Only Title Only Author and Title

Desjardins P, Conklin D (2010) NanoDrop microvolume quantitation of nucleic acids. JOVE-J Vis Exp 5: e2565

Pubmed: Author and Title

Google Scholar: Author Only Title Only Author and Title

Di Baccio D, Tognetti R, Minnocci A, Sebastiani L (2009) Responses of the Populus x euramericana clone I-214 to excess zinc: carbon assimilation, structural modifications, metal distribution and cellular localization. Environ Exp Bot 67: 153-163

Pubmed: Author and Title

Google Scholar: Author Only Title Only Author and Title

Eckhardt U, Marques AM, Buckhout TJ (2001) Two iron-regulated cation transporters from tomato complement metal uptake-deficient yeast mutants. Plant Mol Biol 45: 437-448

Pubmed: Author and Title

Google Scholar: Author Only Title Only Author and Title

Eide D, Broderius M, Fett, J Guerinot ML (1996) A novel iron-regulated metal transporter from plants identified by functional expression in yeast. P Natl Acad Sci USA 93: 5624-5628

Pubmed: Author and Title

Google Scholar: Author Only Title Only Author and Title

Erenoglu EB, Kutman UB, Ceylan Y, Yildiz B, Cakmak I (2011) Improved nitrogen nutrition enhances root uptake, root-to-shoot 
translocation and remobilization of zinc (65Zn) in wheat. New Phytol 189: 438-448

Pubmed: Author and Title

Google Scholar: Author Only Title Only Author and Title

Fageria NK, Filho MB, Moreira A, Guimarães CM (2009) Foliar fertilization of crop plants. J Plant Nutr 32: 1044-1064

Pubmed: Author and Title

Google Scholar: Author Only Title Only Author and Title

Foroughi S, Baker AM, Roessner U, Johnson AAT, Bacic A, Callahan DL (2014) Hyperaccumulation of zinc by Noccaea caerulescens results in a cascade of stress responses and changes in the elemental profile. Metallomics 6: 1671-1682

Pubmed: Author and Title

Google Scholar: Author Only Title Only Author and Title

Foyer CH, Lam H-M, Nguyen HT, Siddique KHM, Varshney RK, Colmer TD, Cowling W, Bramley H, Mori TA, Hodgson JM, et al (2016) Neglecting legumes has compromised human health and sustainable food production. Nat Plants 2: 16112

Pubmed: Author and Title

Google Scholar: Author Only Title Only Author and Title

Geissler C, Powers HJ (2017) Human nutrition. Oxford University Press, Oxford, UK

Pubmed: Author and Title

Google Scholar: Author Only Title Only Author and Title

Gregory PJ, Wahbi A, Adu-Gyamfi J, Heiling M, Gruber R, Joy EJM, Broadley MR (2017) Approaches to reduce zinc and iron deficits in food systems. Global Food Secur-Agr 15: 1-10

Pubmed: Author and Title

Google Scholar: Author Only Title Only Author and Title

Grotz N, Fox T, Connolly E, Park W, Guerinot ML, Eide D (1998) Identification of a family of zinc transporter genes from Arabidopsis that respond to zinc deficiency. P Natl Acad Sci USA95: 7220-7224

Pubmed: Author and Title

Google Scholar: Author Only Title Only Author and Title

Grotz N, Guerinot ML (2006) Molecular aspects of Cu, Fe and Zn homeostasis in plants. Biochim Biophys Acta 1763: 595-608

Pubmed: Author and Title

Google Scholar: Author Only Title Only Author and Title

Gustin JL, Loureiro ME, Kim D, Na G, Tikhonova M, Salt DE (2009) MTP1-dependent Zn sequestration into shoot vacuoles suggests dual roles in Zn tolerance and accumulation in Zn-hyperaccumulating plants. Plant J 57: 1116-1127

Pubmed: Author and Title

Google Scholar: Author Only Title Only Author and Title

Hanikenne M, Talke IN, Haydon MJ, Lanz C, Nolte A, Motte P, Kroymann J, Weigel D, Krämer U (2008) Evolution of metal

hyperaccumulation required cis-regulatory changes and triplication of HMA4. Nature 453: 391-395

Pubmed: Author and Title

Google Scholar: Author Only Title Only Author and Title

Haydon MJ, Cobbett CS (2007) Anovel major facilitator superfamily protein at the tonoplast influences zinc tolerance and accumulation in Arabidopsis. Plant Physiol 143: 1705-1719

Pubmed: Author and Title

Google Scholar: Author Only Title Only Author and Title

Haydon MJ, Kawachi M, Wirtz M, Hillmer S, Hell R, Krämer U (2012) Vacuolar nicotianamine has critical and distinct roles under iron deficiency and for zinc sequestration in Arabidopsis. Plant Cell 24: 724

Pubmed: Author and Title

Google Scholar: Author Only Title Only Author and Title

Hermand V, Julio E, de Borne FD, Punshon T, Ricachenevsky FK, Bellec A, Gosti F, Berthomieu P (2014) Inactivation of two newly identified tobacco heavy metal ATPases leads to reduced $\mathrm{Zn}$ and $\mathrm{Cd}$ accumulation in shoots and reduced pollen germination.

Metallomics 6: 1427-1440

Pubmed: Author and Title

Google Scholar: Author Only Title Only Author and Title

Huma ZE, Khan, Z, Noorka IR, Ahmad K, Bayat AR, Wajid K (2019) Bioaccumulation of zinc and copper in tissues of chicken fed corn grain irrigated with different water regimes. Int J Environ Res 13: 689-703

Pubmed: Author and Title

Google Scholar: Author Only Title Only Author and Title

Hussain D, Haydon MJ, Wang Y, Wong E, Sherson SM, Young J, Camakaris J, Harper JF, Cobbett CS (2004) P-type ATPase heavy metal transporters with roles in essential zinc homeostasis in Arabidopsis. Plant Cell 16: 1327-1339

Pubmed: Author and Title

Google Scholar: Author Only Title Only Author and Title

Ishimaru Y, Suzuki M, Tsukamoto T, Suzuki K, Nakazono M, Kobayashi T, Wada Y, Watanabe S., Matsuhashi S, Nakanishi H, et al (2006) Rice plants take up iron as an Fe3p-phytosiderophore and as Fe2p. Plant J 45: 335-346

Pubmed: Author and Title 
Jean ML, Schikora A, Mari S, Briat JF, Curie C (2005) Aloss-of-function mutation in AtYSL1 reveals its role in iron and nicotianamine seed loading. Plant J 44: 769-782

Pubmed: Author and Title

Google Scholar: Author Only Title Only Author and Title

Keen CL, Gershwin ME (1990) Znc deficiency and immune function. Annu Rev Nutr 10: 415-431

Pubmed: Author and Title

Google Scholar: Author Only Title Only Author and Title

Kolaj-Robin O, Russell D, Hayes KA, Pembroke JT, Soulimane T (2015) Cation diffusion facilitator family: structure and function. FEBS Lett 589: 1283-1295

Pubmed: Author and Title

Google Scholar: Author Only Title Only Author and Title

Kumar S, Stecher G, Li M, Knyaz C, Tamura K (2018) MEGAX: molecular evolutionary genetics analysis across computing platforms. Mol Biol Evol 35: 1547-1549

Pubmed: Author and Title

Google Scholar: Author Only Title Only Author and Title

Kumssa DB, Joy EJ, Ander EL, Watts MJ, Young SD, Walker S, Broadley MR (2015) Dietary calcium and zinc deficiency risks are decreasing but remain prevalent. Sci Rep 5: 10974

Pubmed: Author and Title

Google Scholar: Author Only Title Only Author and Title

Li S, Zhou X, Huang Y, Zhu L, Zhang S, Zhao Y, Chen R (2013) Identification and characterization of the zinc-regulated transporters, iron-regulated transporter-like protein (ZP) gene family in maize. BMC Plant Biol 13: 114

Pubmed: Author and Title

Google Scholar: Author Only Title Only Author and Title

Livak K J, Schmittgen, TD (2001) Analysis of relative gene expression data using real-time quantitative PCR and the 2- $\Delta \Delta C T$ method. Methods 25: 402-408

Pubmed: Author and Title

Google Scholar: Author Only Title Only Author and Title

López-Millán AF, Ellis DR, Grusak MA(2004) Identification and characterization of several new members of the ZP family of metal ion transporters in Medicago truncatula. Plant Mol Biol 54: 583-596

Pubmed: Author and Title

Google Scholar: Author Only Title Only Author and Title

Mäser P, Thomine S, Schroeder JI, Ward JM, Hirsch K, Sze H, Talke IN, Amtmann A, Maathuis FJM, Sanders D, et al. (2001)

Phylogenetic relationship within cation transporter families of Arabidopsis. Plant Physiol 126: 1646-1667

Pubmed: Author and Title

Google Scholar: Author Only Title Only Author and Title

McDonald P, Edwards RA, Greenhalgh JFD, Morgan CA(2002) Animal nutrition. Switzerland: Pearson Education Limited, Harlow, UK Pubmed: Author and Title

Google Scholar: Author Only Title Only Author and Title

Milner MJ, Seamon J, Craft E, Kochian LV(2013) Transport properties of members of the ZP family in plants and their role in Zn and Mn homeostasis. J Exp Bot 64: 369-381

Pubmed: Author and Title

Google Scholar: Author Only Title Only Author and Title

Nei M, Kumar S (2000) Molecular evolution and phylogenetics. Oxford University Press, Oxford, UK

Pubmed: Author and Title

Google Scholar: Author Only Title Only Author and Title

Nicot N, Hausman JF, Hoffmann L, Evers D (2005) Housekeeping gene selection for real-time RT-PCR normalization in potato during biotic and abiotic stress. J Exp Bot 56: 2907-2914

Pubmed: Author and Title

Google Scholar: Author Only Title Only Author and Title

Nölte J (2003) ICP Emission Spectrometry: a practical guide (Vol. 1). Wiley-VCH Weinheim, Germany

Pubmed: Author and Title

Google Scholar: Author Only Title Only Author and Title

Ó Lochlainn S, Bowen HC, Fray RG, Hammond JP, King GJ, White PJ, Broadley MR (2011) Tandem quadruplication of HMA4 in the zinc

$(\mathrm{Zn})$ and cadmium (Cd) hyperaccumulator Noccaea caerulescens. Plos One 6: e17814

Pubmed: Author and Title

Google Scholar: Author Only Title Only Author and Title

Olsen LI, Palmgren MG (2014) Many rivers to cross: the journey of zinc from soil to seed. Front Plant Sci 5: 30

Pubmed: Author and Title 
O'Rourke JA, Fu F, Bucciarelli B, Yang SS, Samac DA, Lamb JF, Li J, Dai X, Zhao PX, Vance CP (2015) The Medicago sativa gene index 1.2: a web-accessible gene expression atlas for investigating expression differences between Medicago sativa subspecies. BMC

Genomics 16: 502

Pubmed: Author and Title

Google Scholar: Author Only Title Only Author and Title

Palmer CM, Guerinot ML (2009) Facing the challenges of Cu, Fe and Zn homeostasis in plants. Nat Chem Biol 5: 333-340

Pubmed: Author and Title

Google Scholar: Author Only Title Only Author and Title

Pedas P, Ytting CK, Fuglsang AT, Jahn TP, Schjoerring JK, Husted S (2008) Manganese efficiency in barley: identification and characterization of the metal ion transporter HvIRT1. Plant Physiol 148: 455-466

Pubmed: Author and Title

Google Scholar: Author Only Title Only Author and Title

Pita-Barbosa A, Ricachenevsky FK, Wilson M, Dottorini T, Salt DE (2019) Transcriptional plasticity buffers genetic variation in zinc homeostasis. Sci Rep 9: 1-11

Pubmed: Author and Title

Google Scholar: Author Only Title Only Author and Title

Prasad AS (2013) Discovery of human zinc deficiency: its impact on human health and disease. Adv Nutr 4: 176-190

Pubmed: Author and Title

Google Scholar: Author Only Title Only Author and Title

Ramesh SA, Shin R, Eide DJ, Schachtman DP (2003) Differential metal selectivity and gene expression of two zinc transporters from rice. Plant Physiol 133: 126-134

Pubmed: Author and Title

Google Scholar: Author Only Title Only Author and Title

Rawat N, Neelam K, Tiwari VK, Dhaliwal HS (2013) Biofortification of cereals to overcome hidden hunger. Plant Breeding $132: 437-445$

Pubmed: Author and Title

Google Scholar: Author Only Title Only Author and Title

Saitou N, Nei M (1987) The neighbor-joining method: a new method for reconstructing phylogenetic trees. Mol Biol Evol 4: 406-425

Pubmed: Author and Title

Google Scholar: Author Only Title Only Author and Title

Saltzman A, Birol E, Bouis HE, Boy E, De Moura FF, Islam Y, Pfeiffer WH (2013) Biofortification: progress toward a more nourishing future. Glob Food Secur-Agr 2: 9-17

Pubmed: Author and Title

Google Scholar: Author Only Title Only Author and Title

Sankaran RP, Huguet T, Grusak MA(2009) Identification of QTL affecting seed mineral concentrations and content in the model legume Medicago truncatula. Theor Appl Genet 119: 241-253

Pubmed: Author and Title

Google Scholar: Author Only Title Only Author and Title

Sasaki H, Hirose T, Watanabe Y, Ohsugi R (1998) Carbonic anhydrase activity and CO2-transfer resistance in Zn-deficient rice leaves. Plant Physiol 118: 929-934

Pubmed: Author and Title

Google Scholar: Author Only Title Only Author and Title

Sasaki A, Yamaji N, Mitani-Ueno N, Kashino M, Ma JF (2015) Anode-localized transporter OsZP3 is responsible for the preferential distribution of $\mathrm{Zn}$ to developing tissues in rice. Plant $\mathrm{J}$ 84: 374-384

Pubmed: Author and Title

Google Scholar: Author Only Title Only Author and Title

Sharma SS, Dietz KJ, Mimura T (2016) Vacuolar compartmentalization as indispensable component of heavy metal detoxification in plants. Plant Cell Environ 39: 1112-1126

Pubmed: Author and Title

Google Scholar: Author Only Title Only Author and Title

Sinclair SA, Senger T, Talke IN, Cobbett CS, Haydon MJ, Kraemer U (2018) Systemic upregulation of MTP2-and HMA2-mediated Zn partitioning to the shoot supplements local Zn deficiency responses. Plant Cell 30: 2463-2479

Pubmed: Author and Title

Google Scholar: Author Only Title Only Author and Title

Sinclair SA Krämer U (2012) The zinc homeostasis network of land plants. BBA-Mol Cell Res 1823: 1553-1567

Pubmed: Author and Title

Google Scholar: Author Only Title Only Author and Title

Talke IN, Hanikenne M, Krämer U (2006) Znc-dependent global transcriptional control, transcriptional deregulation, and higher gene copy number for genes in metal homeostasis of the hyperaccumulator Arabidopsis halleri. Plant Physiol 142: $148-167$ 
Tiong J, McDonald G, Genc Y, Shirley N, Langridge P, Huang CY (2015) Increased expression of six ZP family genes by zinc (Zn) deficiency is associated with enhanced uptake and root-to-shoot translocation of Zn in barley (Hordeum vulgare). New Phytol 207: 1097-1109

Pubmed: Author and Title

Google Scholar: Author Only Title Only Author and Title

Vert G, Grotz N, Dédaldéchamp F, Gaymard F, Guerinot ML, Briat JF, Curie C (2002) IRT1, an Arabidopsis transporter essential for iron uptake from the soil and for plant growth. Plant Cell 14: 1223-1233

Pubmed: Author and Title

Google Scholar: Author Only Title Only Author and Title

Weber M, Harada E, Vess C, Roepenack-Lahaye EV, Clemens S (2004) Comparative microarray analysis of Arabidopsis thaliana and Arabidopsis halleri roots identifies nicotianamine synthase, a $\triangle \mathrm{P}$ transporter and other genes as potential metal hyperaccumulation factors. Plant J 37: 269-281

Pubmed: Author and Title

Google Scholar: Author Only Title Only Author and Title

White PJ (2012) Long-distance transport in the xylem and phloem. In Marschner P, ed. Marschner's mineral nutrition of higher plants. 3rd edn. Academic Press, pp 49-70

Pubmed: Author and Title

Google Scholar: Author Only Title Only Author and Title

White PJ (2016) Biofortification of Edible Crops. eLS 1-8

Pubmed: Author and Title

Google Scholar: Author Only Title Only Author and Title

White PJ, Broadley MR (2005) Biofortifying crops with essential mineral elements. Trends Plant Sci 10: 586-593

Pubmed: Author and Title

Google Scholar: Author Only Title Only Author and Title

White PJ, Broadley MR (2009) Biofortification of crops with seven mineral elements often lacking in human diets-iron, zinc, copper, calcium, magnesium, selenium and iodine. New Phytol 182: 49-84

Pubmed: Author and Title

Google Scholar: Author Only Title Only Author and Title

White PJ, Broadley MR (2011) Physiological limits to zinc biofortification of edible crops. Front Plant Sci 2: 80

Pubmed: Author and Title

Google Scholar: Author Only Title Only Author and Title

White PJ, Pongrac P (2017) Heavy-metal toxicity in plants. In: Shabala S, ed. Plant Stress Physiology, 2nd ed., Wallingford, UK, pp 301331.

Pubmed: Author and Title

Google Scholar: Author Only Title Only Author and Title

White PJ, Thompson JA, Wright G, Rasmussen SK (2017) Biofortifying Scottish potatoes with zinc. Plant Soil 411: 151-165

Pubmed: Author and Title

Google Scholar: Author Only Title Only Author and Title

WHO (2005) Comparative quantification of health risks: global and regional burden of diseases attributable to selected major risk factors. In: Ezzati M, Lopez AD, Rodgers A, Murray CJL. eds. World Health Organization, Geneva, Switzerland.

Pubmed: Author and Title

Google Scholar: Author Only Title Only Author and Title

Wickham H (2011) ggplot2. Wires Comput Stat 3: 180-185

Pubmed: Author and Title

Google Scholar: Author Only Title Only Author and Title

Wintz H, Fox T, Wu YY, Feng V, Chen W, Chang HS, Zhu T, Vulpe C (2003) Expression profiles of Arabidopsis thaliana in mineral deficiencies reveal novel transporters involved in metal homeostasis. J Biol Chem 278: 47644-47653

Pubmed: Author and Title

Google Scholar: Author Only Title Only Author and Title

Yilmaz O, Kazar GA Cakmak I, Ozturk L (2017) Differences in grain zinc are not correlated with root uptake and grain translocation of zinc in wild emmer and durum wheat genotypes. Plant Soil 411: 69-79

Pubmed: Author and Title

Google Scholar: Author Only Title Only Author and Title

Zhao H, Eide D (1996) The yeast ZRT1 gene encodes the zinc transporter protein of a high-affinity uptake system induced by zinc limitation. P Natl Acad Sci USA 93: 2454-2458

Pubmed: Author and Title

Google Scholar: Author Only Title Only Author and Title 